\title{
La conducta sexual del carnero. Revisión
}

\author{
Ram's sexual behavior. Review
}

\author{
Agustín Orihuela Trujilloa
}

\begin{abstract}
RESUMEN
El presente trabajo tiene como objetivo recapitular la literatura disponible sobre factores que influyen en la conducta sexual del carnero. Incluye una descripción de los fundamentos endocrinos básicos, su manifestación en borregos ferales, así como una breve reseña de las conductas de cortejo y cópula. También abarca una descripción de aquellos efectos que tanto a nivel prenatal como durante la infancia pueden afectar la vida reproductiva del animal adulto, considerando prácticas de manejo tales como la separación por sexos al momento del destete, y los problemas posteriores de homosexualidad o inadecuda conducta sexual que pueden mostrar en su madurez. Además, se revisan aspectos de dominacia y fotoperiodo, y cómo estos pueden afectar el éxito reproductivo. Se describen aspectos relacionados con la selección del compañero de monta y colección del semen. Finalmente, se documentan algunas pruebas a corral, desarrolladas con el fin de determinar cuáles son los carneros que pueden tener mayor éxito reproductivo en condiciones de campo.
\end{abstract}

PALABRAS CLAVE: Comportamiento reproductivo, Ovinos, Reproducción, Libido, Capacidad de servicio.

\begin{abstract}
The purpose of this manuscript is to summarize the literature regarding factors influencing rams' sexual behavior. It includes a description of: the fundamental endocrine basis of sexual behavior, its manifestation in feral sheep, a brief description of ram's courting, and copulatory behaviors. It also describes how some prenatal and childhood conditions can impact reproductive performance in mature animals, in addition to management practices, such as separation by sexes at weaning, and the later problems of homosexuality or inadequate sexual behavior that might some rams develope. Furthermore, the effects of dominance and photoperiod, and their effect in the reproductive success, together with some aspects related to mate selection are also described. Some considerations during semen collection are stated as well, and finally, several useful tests that have been developed under pen conditions to determine which rams could be successful breeders in the field are illustrated.
\end{abstract}

KEY WORDS: Reproductive performance, Sheep, Reproduction, Libido, Serving capacity.

\section{INTRODUCCIÓN}

Los carneros poseen características muy específicas en su comportamiento sexual, que les hacen un modelo particular para el estudio de esta conducta, y aunque se analizarán a detalle más adelante, conviene mencionar algunas. Los carneros son en general reproductores estacionales que muestran una libido muy alta durante los días cortos(1). Requieren un umbral en la concentración de testosterona para adquirir y manifestar la

\section{INTRODUCTION}

The rams have very specific characteristics in their sexual behavior, which make them a particular model for the study of this conduct, and although this will discuss it in detail later, it is worth mentioning some characteristics. The rams are generally seasonal players, showing a very high libido during short days(1). They require a threshold concentration of testosterone to acquire and demonstrate sexual conduct when adults(2). Estrogens, coming from

Recibido el 26 de enero de 2012. Aceptado el 29 de octubre de 2012.

a Facultad de Ciencias Agropecuarias de la Universidad Autónoma del Estado de Morelos. Av. Universidad 1001 Col. Chamilpa, 62210 Cuernavaca, Morelos, México. aorihuela@uaem.mx. 
conducta sexual cuando adultos(2). Los estrógenos, provenientes de la testosterona circulante, son críticos para el mantenimiento de esta conducta(3). Estudios neuro-químicos y neuro-anatómicos sugieren que la conducta homosexual de los carneros puede ser una consecuencia de variaciones individuales en la diferenciación sexual del cerebro(3). Los carneros, a diferencia de bovinos y caprinos, no se estimulan sexualmente al presenciar la cópula de otros ovinos(4). La exposición ante hembras durante una edad temprana favorece el desempeño sexual, pero no evita que algunos machos muestren preferencias homosexuales(5). Con base en éstas y otras características, existe una basta información en la literatura científica sobre el tema, misma que se proporciona en las secciones siguientes.

\section{REGULACIÓN ENDOCRINA DE LA ACTIVIDAD NEURAL Y REPRODUCTIVA}

La actividad sexual en los carneros se encuentra bajo el control de hormonas androgénicas que actúan principalmente en el área preóptica del hipotálamo(1), como lo demuestran los siguientes hallazgos: la implantación de testosterona directamente en esta área, reinstaura la conducta copulatoria previamente suprimida por la castración del animal adulto; su estimulación eléctrica induce a la cópula; la actividad sexual incrementa su actividad metabólica; y su destrucción, suprime la conducta sexual. Conjuntamente con la información hormonal, el área preóptica recibe información sensorial del órgano vomeronasal y genitales a través de la amígdala, induciendo reflejos genitales y patrones copulatorios(6).

Las hormonas androgénicas, como ya se mencionó, requieren cierto nivel para el desarrollo y expresión normal de la conducta sexual del macho, y contrariamente a lo que pudiera pensarse, concentraciones mayores a este nivel, no incrementan la libido(3).

Vázquez y Orihuela(7) encontraron que la aplicación del moco vaginal de ovejas en celo circulating testosterone, are critical for the maintenance of such conduct(3). Neuroanatomical and neuro-chemical studies suggest that homosexual conduct of rams can be a consequence of individual variations in the sexual differentiation of the brain(3). Rams, unlike cattle, and goats, are not sexually stimulated by witnessing the mounting of other sheep(4). Exposure to females during an early age promotes sexual performance, but does not prevent that some males show homosexual preferences(5). Based on these and other characteristics, there is enough information in the scientific literature on the subject, same that is provided in the following Sections.

\section{ENDOCRINE REGULATION OF NEURAL AND REPRODUCTIVE ACTIVITY}

Sexual activity in the rams is under the control of androgenic hormone acting mainly in the preoptic area of the hypothalamus(1). This is evidenced by the following findings: the implantation of testosterone directly into this area restores the copulatory behavior previously suppressed by the castration of the adult animal; its electrical stimulation leads to copulation; sexual activity increases their metabolic activity; and their destruction, suppresses sexual behavior. Together with the hormonal information, the preoptic area receives sensory information from the vomeronasal body and genitals through the amygdala, inducing genital reflexes and copulatory patterns(6).

Androgenic hormones, as already mentioned, require some level for normal expression of the male sexual behavior and development, and contrary to what one might think, concentrations above this level, do not increase the libido(3).

Vazquez and Orihuela(7) found that the application of vaginal mucus of ewes in estrus in the nose of the rams, causes a significant increase in circulating testosterone levels. However, this increase in hormone levels is rather related to the increase of aggressiveness, enabling males to compete for females in estrus during the reproductive season(8). 
en el morro de los carneros, provoca un incremento significativo en los niveles de testosterona circulante. Sin embargo, este incremento está más bien relacionado con el aumento de la agresividad que habilita a los machos para competir por hembras en celo durante la temporada reproductiva( 8 ).

Las razas ovinas muestran variaciones significativas en la concentración de testosterona a lo largo del año(9), que pueden ir desde niveles bajo el umbral y sobre el umbral en temporadas no reproductivas y reproductivas, respectivamente, determinando la manifestación de la conducta sexual y la agresividad en estas dos temporadas. Durante la temporada reproductiva, los niveles circulantes de testosterona, normalmente se encuentran por arriba del umbral que se necesita para que el animal manifieste actividad sexual. Esto lo demuestra el hecho de que los niveles de testosterona plasmática requeridos para que carneros castrados puedan mostrar conducta copulatoria son menores a los que se encuentran en carneros intactos, por lo que parece haber otros factores además, responsables de la variación en la libido(2), independientes de la concentración de testosterona. Aunado a lo anterior, Pinckard et al(10) demostraron que el restablecimiento vía exógena de las concentraciones de estradiol-17 beta a niveles fisiológicos en carneros adultos castrados, tampoco restablecía las conductas sexuales a los niveles observados previos a la castración, ni inducía éstas en aquellos machos sexualmente inactivos. De forma similar, dosis terapéuticas de testosterona o LH tampoco incrementan la libido en los carneros enteros, ni revierten la orientación de carneros homosexuales(11).

Las diferencias en el patrón de secreción de LH o de respuesta a su hormona de liberación (GnRH) son posiblemente las responsables de la diferencia entre machos con alto y bajo desempeño sexual, y nuevamente, no la concentración de éstas, siempre y cuando se encuentren por arriba del umbral requerido. Esta relación entre las gonadotropinas y la conducta,
The breeds show significant variations in the concentration of testosterone throughout the year(9), variations that can range from under the threshold and above the threshold levels in non-reproductive and reproductive seasons respectively, determining the manifestation of sexual behavior and aggression in these two seasons. During the reproductive season, the circulating levels of testosterone in the ram, are normally encountered above the threshold that is needed, so that the animal manifest sexual activity. This was evidenced by the fact that the required testosterone plasma levels for castrated rams that show copulatory behavior are smaller than those found in the intact rams, by what appears to be other factors also, responsible for the variation in libido, independent of the testosterone concentration(2). Coupled with the above, Pinckard et al(10) demonstrated that the recovery via exogenous of estradiol-17 beta concentrations to physiological levels in adult castrated rams, nor restored sexual behavior to the levels observed prior to castration, or induced in those sexually inactive males. Similarly, therapeutic doses of testosterone or LH does not increase libido in the entire rams, nor reverse the orientation of homosexual rams(11).

Differences in the pattern of $\mathrm{LH}$ secretion or response to their releasing hormone (GnRH) are possibly responsible for the difference between males with high and low sexual behavior, and again, not the concentration of these, provided are above the required threshold. This relationship between gonadotropins and behavior is supported by seasonal patterns. Outside the tropics, variations in sexual activity during the year are notorious, being both the concentrations of FSH and $\mathrm{LH}$ as sexual activity, lower during the spring and early summer when the day length increases. As a result, the production of testosterone also tends to be low in this period. In support of this, Parthasarathy et al(12) showed that repeated immunization against GnRH (immunocastration) in the rams causes reduction in 
se ve apoyada por patrones estacionales. Fuera de la zona tropical, las variaciones en la actividad sexual durante el año son notorias, siendo tanto las concentraciones de FSH y $\mathrm{LH}$ como la actividad sexual, menores durante la primavera e inicios del verano cuando la duración del día se incrementa. Consecuentemente la producción de testosterona también tiende a ser baja en este periodo. En apoyo a lo anterior, Parthasarathy et al(12) demostraron que la inmunización repetida contra GnRH (inmunocastración) en los carneros provoca la reducción de testosterona y la supresión de la conducta sexual (montas y eyaculaciones), técnica que podría ser de utilidad en aquellas situaciones en que se desee inhibir el comportamiento sexual del macho en forma temporal, como sucede en el caso de engordas intensivas(13). Sin embargo, hay que considerar que una sola administración de anticuerpos anti GnRH no es suficiente para afectar la conducta sexual en animales adultos, aunque sí lo es en carneros jóvenes. Cui et al(14) demostraron que una sola aplicación de inmunización contra $\mathrm{GnRH}$ en corderos de tres meses de edad, es una buena alternativa para la castración quirúrgica, al tener efectos similares evitando cirugías tan agresivas.

Otra de las hormonas importantes en el comportamiento sexual del carnero, es la melatonina, factor clave entre el fotoperiodo y la reproducción, ya que la producción de esta hormona aumenta durante las noches largas, favoreciendo la secreción de $\mathrm{GnRH}$ y disminuyendo la secreción de prolactina $(15,16)$. Sin embargo, tanto los niveles altos de prolactina observados fuera de la estación reproductiva como los extremadamente bajos, producto del tratamiento con bromocriptina, se asocian con una disminución del comportamiento sexual(17). Es importante considerar que una de las funciones principales de la prolactina en el macho, es la de estimular la síntesis de testosterona en las células de Leydig(18,19), lo que podría explicar al menos en parte, la modulación en la intensidad de la expresión de la conducta sexual del macho, particularmente al reinicio de la estación reproductiva. testosterone production and suppression of sexual behavior (mating and ejaculations). Technique that could be useful in situations where you want to inhibit the sexual behavior of male on a temporary basis, as in the case of intensive feedlots(13). However, it should be consider that a single administration of $\mathrm{GnRH}$ antibodies is not enough to affect sexual behavior in adult animals, although it is in young rams. Cui et al(14) showed that a single application of immunization against $\mathrm{GnRH}$ in 3 mo-old lambs, is a good alternative to surgical castration, avoiding so aggressive surgeries.

Melatonin is another of the important hormones in the sexual behavior of the ram, key factor between photoperiod and reproduction, since the production of this hormone increases during the long nights, promoting the secretion of $\mathrm{GnRH}$ and decreasing the secretion of prolactin $(15,16)$. However, also the high prolactin levels observed outside of the reproductive season, or the extremely low levels, caused by bromocriptine treatment, both are associated with a decrease in sexual behavior(17). It is important to consider that one of the main functions of prolactin in the male, is to stimulate the synthesis of testosterone in the Leydig cells $(18,19)$, which could explain at least in part, the modulation in the intensity of the expression of the sexual behavior of the male, particularly at the resumption of the reproductive season.

On the other hand, the mounts and intromission of the penis are also associated with rising prolactin concentrations and other hormones such as cortisol. While aspects of courtship are more related to the elevation on the concentration of $\mathrm{LH}$ and testosterone.

At the time of intercourse, moreover, is an increase in the concentration of oxytocin(20), hormone that, among other things, is related to the contractions of the epididymis during ejaculation, sperm production, and the steroidogenesis(21-23). Whereas prolactin as dynorphin (an endogenous opioid), assist in the refractory period that occurs after ejaculation. 
Por otra parte, la monta y la intromisión del pene también están associadas con la elevación en las concentraciones de prolactina y otras hormonas como el cortisol. Mientras que los aspectos del cortejo están más relacionados con la elevación en la concentración de LH y testosterona.

Al momento de la cópula, además, se tiene un aumento en la concentración de oxitocina(20), hormona que entre otras cosas está relacionada con las contracciones del epidídimo durante la eyaculación, la producción de espermatozoides, y la esteroidogenesis(21-23), mientras que la prolactina al igual que la dinorfina (un opioide endógeno), parecen coadyuvar en el periodo refractario que tiene lugar después de la eyaculación.

Otras sustancias como la dopamina y seratonina juegan un papel importante en la estimulación o inhibición de la eyaculación, respectivamente. Mientras que la norepinefrina ha demostrado tanto efectos estimulatorios como inhibitorios en la cópula(24). Además de la época del año, la respuesta endocrina se ve afectada también por el tiempo de exposición ante las hembras y la experiencia del carnero, por lo que no es de sorprender que Borg(25) observara respuestas endocrinas más consistentes en animales con experiencia sexual, con un acceso restringido a las hembras, y durante la temporada reproductiva.

Aunado a la situación endocrina, se ha postulado que las diferencias en la orientación sexual y libido podrían estar en el cerebro. Roselli et al(26) identificaron un grupo celular en el área pre-óptica media del hipotálamo anterior en borregos adultos, significativamente mayor en los machos que en las hembras. Además, el volumen de este núcleo es dos veces más grande en los carneros con orientación heterosexual en comparación con los homosexuales. Así mismo, Alexander et al(27) encontraron que carneros con alta capacidad de servicio muestran más conductas de investigación hacia las hembras en estro y otros
Other substances such as dopamine and serotonin play an important role in the stimulation or inhibition of ejaculation, respectively. While the norepinephrine has demonstrated both effects, inhibitory and stimulatory during intercourse(24). In addition to the time of year, the endocrine response is affected also by the exposure time to females and the experience of the ram, so it is no surprise that Borg(25) observed more consistent endocrine responses with sexual experienced rams, with restricted access to females, and during the breeding season.

In addition to the endocrine status, it has been postulated that differences in sexual orientation and libido may be in the brain. Roselli et al(26) identified in adult sheep a cell group in the pre-optic area of the anterior hypothalamus, significantly higher in males than in females. The volume of this nucleus is also twice as large in the rams with heterosexual orientation compared to homosexuals. Likewise, it was found(27) that rams with high service capacity show more investigatory behavior toward other males and females in estrus. The rams with high service capacity seem to discriminate the sex of the stimulus animal and generate a neuroendocrine response (increase of LH plasma levels) only when exposed to females in estrus. Sensory signals emitted by the ewe in estrus are not detected by males with low service capacity or homosexual rams, or are not attractive enough to cause further pursuit by them.

The domestic ram shows a natural variation in terms of their sexual orientation; approximately between 6 to $10 \%$ of the male population prefers another male as a sexual companion, contrary to the majority of males who prefer to mount females.

The homosexual rams show different responses to stress and hormonal profiles that the heterosexuals. These differences include fewer levels of circulating testosterone that is incremented after being subjected to anesthesia. Furthermore, homosexual males, present lower 
machos. Los carneros con alta capacidad de servicio parecen discriminar el sexo del animal estímulo y generar una respuesta neuroendocrina (incremento de los niveles de LH plasmáticos) únicamente cuando se les expone ante hembras en estro. Las señales sensoriales que emiten las borregas en celo no son detectadas por machos con baja capacidad de servicio ni carneros homosexuales, o no son lo suficientemente atractivas para provocar mayor investigación por parte de ellos.

El carnero doméstico manifiesta una variación natural en cuanto a su orientación sexual; aproximadamente entre un 6 a $10 \%$ de la población de machos prefiere como compañero a otros machos, contrariamente a la mayoría de los machos, quienes prefieren montar hembras.

Los carneros homosexuales muestran perfiles hormonales y respuestas al estrés diferentes de sus contra partes heterosexuales. Estas diferencias incluyen una menor cantidad en los niveles de testosterona circulante que se incrementa después de verse sometidos a anestesia. Además, en los machos homosexuales, en comparación con los heterosexuales, se encuentran menores niveles de actividad de la aromatasa en el área preóptica medial y receptores de estrógeno en la amígdala(28). Es necesario recordar que el área preóptica del hipotálamo es una región del cerebro sensitiva a esteroides, que contiene una elevada concentración de receptores de andrógenos y estrógenos. Ahí, la conversión de testosterona a estradiol por la aromatasa, es parte de un mecanismo mediante el cual los andrógenos facilitan la expresión de la conducta sexual(29). Así mismo, Perkins et al(30) encontraron que la cantidad de receptores de estradiol que se encuentran en la amígdala de carneros homosexuales es similar a los de las ovejas, pero distintos a los de los carneros heterosexuales. Por todo esto, las diferencias en la cantidad de receptores entre los carneros heterosexuales y homosexuales sugieren que la amígdala sirve como un vínculo para el levels of aromatase activity in the medial preoptic area and estrogen in the amygdala(28). It is necessary to remember that the preoptic area of the hypothalamus is a brain area sensitive to steroids, containing a high concentration of androgen and estrogen receptors. Hence the conversion of testosterone to estradiol by aromatase, is part of a mechanism by which androgens facilitate the expression of sexual behavior(29). Likewise, Perkins et al(30) found that the number of recipients of estradiol found in the amygdala of homosexual rams is similar as in ewes, but different from heterosexual rams. Thus, differences in the number of receptors between heterosexual and homosexual rams suggest that the amygdala serves as a link for the registration of potential copulations, and that not only plays a role in sexual behavior but it could be involved in the sexual orientation of the rams.

In summary, changes in the levels of melatonin, its impact on gonadotropins and other hormones such as testosterone, are responsible for both, the seasonality of the rams and the manifestation of their sexual behavior during the breeding season. However, much of the mechanisms of action, as well as the participation of nuclei brain in modulation and address of sexual behavior of male, remain unclear, so more studies that can assist in the understanding of these processes are necessary.

\section{FERAL RAMS}

The sexual behavior of the Soay sheep in the wild (feral) can give us the key to the sexual behavior of the ram under conditions little altered by man. Male lambs in this type of animal, stay beside their mothers since the end of the spring when they are born, until next fall when they begin to pursue females. Adult ewes will reject them until the males are bigger. Meanwhile, the adult rams live in exclusive separated groups of males, in different grazing areas. Shortly before females come into estrus, adult rams will begin to move towards the groups of females, fight against males from 
registro de cópulas potenciales, y que no sólo juega un papel en la conducta sexual sino que podría estar involucrada en la orientación sexual de los carneros.

En síntesis, los cambios en los niveles de melatonina, su repercusión en las gonadotropinas y otras hormonas como la testosterona, son responsables tanto de la estacionalidad de los carneros como de la manifestación de su comportamiento sexual durante la época reproductiva. Sin embargo, buena parte de los mecanismos de acción, así como de la participación de los núcleos cerebrales en la modulación y dirección del comportamiento sexual de macho, permanecen poco claras, por lo que son necesarios más estudios que permitan coadyuvar en el entendimiento de estos procesos.

\section{BORREGOS FERALES}

El comportamiento sexual del borrego Soay en vida silvestre (feral) puede darnos la clave de la conducta sexual del carnero bajo condiciones poco alteradas por el hombre. Los corderos machos en este tipo de animales, permanecen al lado de sus madres desde finales de la primavera que es la época en que nacen, hasta el otoño siguiente, cuando empiezan a perseguir a las hembras. Las ovejas adultas los rechazarán hasta que los machos sean mayores. Mientras tanto, los carneros adultos viven en grupos separados exclusivos de machos, en áreas diferentes de pastoreo. Poco antes de que las hembras entren en celo, los carneros adultos empezarán a moverse hacia los grupos de hembras, embestirán contra machos de otros grupos, pero tolerarán a aquéllos de su mismo grupo(31).

A medida que la temporada reproductiva avanza, los carneros adultos competirán contra cualquier macho, indistintamente. Estos combates consisten en choques de cabeza contra cabeza. Todo esto sucede antes de que las ovejas se tornen receptivas. Cuando las ovejas entran en celo, la competencia entre los carneros other groups, but tolerate those of the same group(31).

As the breeding season progress, the adult rams will compete against any male. These bouts consist of head-head crashes. All this happens before the ewes become receptive. When ewes come in heat, competition among the rams decrease, and they turn their attention toward copulation. The winner male of the majority of fighting, is the one who now will serve the largest number of females, and will do so in a sequential manner, according to a female per day, or half day, conducting courtship behaviors and accompanying her, to avoid mounts from other males(32). Recently it has been shown in Soay rams, that the proportion of pregnant females by dominant males decreases throughout the sexual season, probably due to the energetic cost which involves covering the largest number and maintain its hierarchical position at the same time, or perhaps to sperm depletion(33).

Since the start of the competition with other males, up to the end of the breeding season, the ram eats less and loses weight(32). However, their reproductive capacity is constrained by the season, such as the ewe, and only extreme conditions of malnutrition may affect their sexual performance within the season.

Males are less affected than females by photoperiod, and although libido lowers during the months of long days, this does not disappear completely, as well as either spermatogenesis, then, in theory, females in heat can be fertilized at any time, despite that the semen quality is lower during the spring $(34,35)$.

The sexual behavior of feral sheep can give us a general idea of the domestic sheep conduct, because in theory all domestic sheep breeds have the same origin. The promiscuous behavior, seasonality and many features of courtship are similar. However, management and genetic selection in search of reproductive seasons of longer duration and increased prolificacy have 
disminuye y estos vuelcan su atención hacia la cópula. El macho ganador de la mayoría de los combates, es aquel que ahora dará servicio a la mayor cantidad de hembras, y lo hará de manera secuencial, atendiendo a una hembra por día, o medio día, realizando conductas de cortejo y acompañándole, para evitar que otros machos la monten(32). Recientemente se ha demostrado en carneros Soay, que la proporción de hembras preñadas por los machos dominantes disminuye a lo largo de la temporada sexual, probablemente debido al costo energético que implica cubrir a la mayor cantidad y mantener su posición jerárquica al mismo tiempo, o quizá al agotamiento de las reservas espermáticas(33).

Desde el inicio de la competencia con otros machos, hasta el final de la temporada reproductiva, el carnero come menos y pierde peso (32). Sin embargo, su capacidad reproductiva se ve limitada por la estación, como en la oveja, y sólo condiciones extremas de desnutrición podrían afectar su desempeño sexual dentro de la temporada.

Los machos son menos afectados que las hembras por el fotoperiodo, y aunque sí baja la libido durante los meses de días largos, ésta no desaparece por completo, así como tampoco la espermatogenesis, por lo que en teoría, las hembras en celo podrían ser fertilizadas durante cualquier época, pese a que la calidad del semen es menor durante la primavera $(34,35)$.

El comportamiento sexual de ovinos ferales puede darnos una idea general de la conducta del carnero doméstico, pues en teoría todas las razas de borrego doméstico tienen un mismo origen. El comportamiento promiscuo, la estacionalidad y muchas características de cortejo se mantienen semejantes. Sin embargo, el manejo y la selección genética en busca de temporadas reproductivas de mayor duración y mayor prolificidad, han generado un rango de razas con ciertas diferencias fisiológicas y conductuales.

Hoy en dìa, en términos generales las razas de pelo presentan poca estacionalidad, razas de generated a range of breeds with behavioral and physiological differences.

Today, in general terms, the hair breeds have little seasonality, breeds from median latitudes as the Merino, have sexual conduct predominantly influenced by seasonal nutrition changes, while most Nordic breeds have reproductive seasons well defined by changes in the duration of the day(36).

\section{MATING}

Motor neurons that innervate the pelvic organs involved in copulation, as well as erection and ejaculation processes, are controlled by circuits of neurons that are found in the dorsomedial and dorsolateral nuclei of lumbar and sacral regions of the spinal $\operatorname{cord}(37,38)$. In these circuits, the brain mechanisms can exercise both, excitatory and inhibitory control.

According to Odagiri et al(39) copulation starts from the approach of the ram or the monitoring of a particular female, and ends with ejaculation; consists of eight units of behavior: tracking or approach, rest chin, flehmen, mount, nasal contact, butting, rub on the flank of the female and raising a fore arm. When these researchers analyzed the frequency of any combination of two units of behavior considering the predecessor and the next, observed that the most common chain was the approach-raise forward arm-butting-rest chin-mount. They also concluded that the flehmen and naso-vaginal contact, not led to riding in a direct way. It is believed that these units are rather associated with the olfactory perception and identification of the physiological state of the female, and although they also belong to the sexual repertoire, they may have a function independent of the other six behavioral units constituting the intercourse.

The first phase of sexual behavior implies that the male identify the physiological state of the female, dedicating considerable time sniffing the genitals and the sheep urine, what is followed by a flehmen response, whose function is to 
latitudes medias como la Merino tienen una conducta sexual predominantemente influenciada por cambios estacionales en la nutrición, mientras que las razas más nórdicas tienen temporadas reproductivas bien definidas por los cambios en la duración del día(36).

\section{LA CÓPULA}

Las neuronas motoras que inervan los órganos pélvicos implicados en la cópula, así como los procesos de erección y eyaculación, están controlados por circuitos de neuronas que se encuentran en los núcleos dorsomedial y dorsolateral de las regiones lumbar y sacra de la médula espinal $(37,38)$. Circuitos donde los mecanismos cerebrales pueden ejercer un control tanto excitatorio como inhibitorio.

De acuerdo con Odagiri et al(39) la cópula inicia desde el acercamiento del carnero o el seguimiento en particular de una hembra, y termina con la eyaculación; está compuesta por ocho unidades de conducta: seguimiento o acercamiento, descanso de la barbilla, flehmen, monta, contacto nasal, topeteo, restregarse en el flanco de la hembra y elevar una extremidad delantera. Cuando estos investigadores analizaron la frecuencia de cualquier combinación de dos unidades de conducta considerando la antecesora y la siguiente, observaron que la cadena más común fue la de: seguir-elevar su extremidad anterior-topetear-descanso de barbilla-monta. Concluyeron también que el flehmen y el contacto naso-vaginal no condujeron a la monta de manera directa, por lo que se cree que estas unidades están más bien asociadas con la percepción olfativa y la identificación del estado fisiológico de la hembra, y que aunque también pertenecen al repertorio sexual, pueden tener una función independiente de las otras seis unidades comportamentales que constituyen la cópula.

La primera fase del comportamiento sexual implica que el macho identifique el estado fisiológico en que se encuentra la hembra, para esto dedica un tiempo considerable olfateando insert fluid into the vomero-nasal organ for the identification of the sex pheromones. The rams show this reaction less frequently to ewes in heat, apparently because they urinate less $(40)$.

A characteristic of the males is that they can discriminate the urine of a female in heat of another that is not(41). Anosmic animals, under extensive conditions, show some difficulties to identify females in estrus, approaching ewes indiscriminately, but they manage to identify those in heat, presumably through visual messages or hearing (28). In fact, under intensive conditions, rams may ignore any sensorial message to detect heat and rely almost exclusively on the immobility of the female to start riding.

The ability of the rams to discriminate between the urine of sheep in estrus and diestrus was demonstrated through operant conditioning testing (41). Flehmen, was not observed in this study, which supports the idea that is not essential to the identification, and it can only play a secondary role in the characterization of pheromone or courtship(42).

During a second phase, the courtship, the male can also lick genitals of the female as a form of tactile stimulation that can also be part of a procedure to test whether the female is in heat, whether the ewe leaves, or she keeps still. Then the male places behind the female making contact with his shoulder and the ewe, lift and lower one of their fore arm keeping it rigidly and frequently hitting her ventral part. The Suffolk breed performs this behavior more often than others (43).

During courtship, the male also rotates and gently lowers the level of his head while his shoulder comes in contact with a flank of the ewe, and at the same time emitted low tone vocalizations(44).

The manifestation of courtship behavior units decrease when the rams are under competitive situations. The rams with low service capacity 
los genitales y orina de la oveja, a lo que sigue una respuesta de flehmen, cuya función es sólo la de introducir líquido hacia el órgano vomeronasal para la identificación de las feromonas sexuales. Los carneros muestran esta reacción con menor frecuencia ante ovejas en celo, aparentemente porque éstas orinan menos $(40)$.

Una característica de los machos, es que pueden discriminar la orina de una hembra en celo de otra que no lo está(41). Animales anósmicos bajo condiciones extensivas, muestran algunas dificultades para la identificación de hembras en celo, aproximándose indiscriminadamente a las ovejas, pero logran identificar aquéllas en celo, presumiblemente a través de mensajes visuales o auditivos(28). De hecho, bajo condiciones intensivas, los carneros pueden hacer caso omiso de cualquier mensaje sensorial para detectar el celo y depender casi exclusivamente de la inmovilidad de la hembra para iniciar la monta.

La habilidad de los carneros para discriminar entre la orina de ovejas en celo y en diestro se demostró a través de pruebas de condicionamiento operante(41). En este estudio no se observó flehmen, lo que apoya la idea de que no es indispensable en la identificación, y que puede jugar un papel secundario en la caracterización de feromonas o en el cortejo(42).

Durante una segunda fase, la de cortejo, el macho puede también lamer los genitales de la hembra como una forma de estimulación táctil como parte de un procedimiento para probar si la hembra está en celo. Si ésta, en respuesta, permanece quieta o se va. Luego, el macho se coloca detrás de la hembra haciendo contacto con su hombro y la oveja, levanta y baja uno de sus miembros anteriores manteniéndole en forma rígida y con frecuencia golpeando su parte ventral. La raza Suffolk realiza esta conducta con mayor frecuencia que otras(43).

Durante el cortejo, el macho también gira y baja el nivel de su cabeza suavemente mientras su hombro entra en contacto con un flanco de are more efficient than the high-service capacity when riding ewes in estrus under situations without competition. However, under situations of competition, although males alter their strategies of courtship, the low capacity are most affected by the presence of a dominant ram, that the latter in the presence of low service capacity rams(45).

Several mounts characterized by pelvic thrusts without intromission, can interrupt the sequence of behavior units. But when the tip of the gland's penis meets the vaginal mucosa, then a vigorous pelvic contraction occurs in response, accompanied by a movement of propulsion of the hind legs, in which both are shortly suspended in air, happening immediately ejaculation and a movement of the head back in a synchronous manner. Right away, the male dismounts and remains next to the female with a lack of sexual interest known as "refractory" or "latency"; after this period, the male restarted his courtship behavior with the same female, or looking for a new female with whom to sexually interact. This period varies in duration and can take from several minutes to more than one hour. Period in which the female may remain near the male, or move in search of another ram, if conditions are permitted.

The period between ejaculates increases as number of ejaculations is increased, but it is subject to large individual variation. However, there are some general principles. For example, if a male repeatedly mounted a female, the introduction of a different ewe will result in a recovery of sexual interest(46). Another way to handle this behavior known as "Coolidge" effect, is to offer a ram several ewes in heat; he then copulates three times more than if only had exposed one at a time (47). The resurgence of the libido when interacting with a new female encourages males to redirect their attention toward other females after some mating with a same ewe (48). This is a reproductive advantage, since the males who investigate and inseminate many females; potentially leave more offspring 
la oveja, al tiempo que emite vocalizaciones de tonos bajos(44).

La manifestación de unidades de conducta de cortejo es menor cuando los carneros se encuentran bajo situaciones de competencia. Los carneros con baja capacidad de servicio son más eficientes que los de alta capacidad de servicio al montar borregas en estro bajo situaciones sin competencia. Sin embargo, bajo situaciones de competencia, aunque los machos modifican sus estrategias de cortejo, los de baja capacidad se ven más afectados por la presencia de un carnero dominante, que estos últimos ante la presencia de carneros de baja capacidad de servicio(45).

Varias montas caracterizadas por movimientos pélvicos sin intromisión, pueden interrumpir la secuencia de las unidades de conducta. Pero cuando la punta del glande entra en contacto con la mucosa vaginal, entonces en respuesta se produce una contracción pélvica vigorosa, acompañada de un movimiento de propulsión de las patas traseras, en las que momentáneamente ambas quedan suspendidas en el aire, ocurriendo inmediatamente la eyaculación y un movimiento de la cabeza hacia atrás de manera sincrónica. En seguida, el macho desmonta y permanece junto a la hembra durante un periodo de falta de interés sexual conocido como "refractario" o "de latencia", transcurrido este, el macho reinicia su comportamiento de cortejo con la misma hembra, o busca una nueva hembra con quien interactuar sexualmente. Este periodo varía en duración y puede llevar desde algunos minutos hasta más de una hora. Periodo durante el cual, la hembra puede permanecer cerca del macho o desplazarse en busca de otro carnero, si las condiciones lo permiten.

El periodo entre eyaculados aumenta a medida que se incrementa el número de eyaculaciones, pero está sujeto a gran variación individual. Sin embargo, existen algunos principios generales. Por ejemplo, si un macho monta repetidamente a una hembra, la introducción de una oveja diferente provocará una recuperación del interés to the next generation in comparison to those rams who remain with a single female.

In extensive conditions, some researchers have found a diurnal pattern in sexual behavior, noting that most of the copulations occur in peaks, early in the morning and late in the afternoon, with little activity at night and almost zero between 2300 and $0300 h^{(49,50)}$. In addition to the time of day, other factors involved are high ambient temperatures and severe weight loss, as agents that suppress sexual activity(51). Breeds originating in temperate climates are more affected than those of tropical origin during hours of intense radiation(52).

Under controlled conditions, Price(53) found that the average number of ejaculations by 16 sheep exposed to females during two periods of 60 min, fluctuated between 0.0 and 6.5 , with a coefficient of variation equal to 0.54 . This considerable genetic variation can repay in large improvement in a short time when selection programs are implemented(54). For example, Bench et al(54) found significant differences between the sexual behavior of lambs from rams with high and low service capacity in just one generation(55). Similarly, Kridli et al(56) showed the genetic breeds variation, when performed a series of crosses and prove that the Romanov $x$ Awassi lambs have a greater frequency of mating than the Awassi and F1 Charollais $x$ Awassi, while the Awassi had greater capacity to breed with fat-tail females than the Charollais $x$ Awassi and Romanov $x$ Awassi.

In summary, the copulatory behavior is the result of a multi-unit behavior, covering the identification of the female, the courtship, and ejaculation. This behavior may be affected by environmental conditions such as the dominance or the presence of females in heat among others. Factors that must be known by its applicability in controlled breeding of sheep reproduction. This will permit designing management techniques that allow making maximum use of the reproductive advantages that a sire can offer. 
sexual(46). Otra forma de manejar esta conducta conocida como efecto "Coolidge", consiste en ofrecer a un carnero varias ovejas en celo; entonces copulará tres veces más que si sólo se hubiese expuesto ante una a la vez(47).

El resurgimiento de la libido al interactuar con una nueva hembra estimula a los machos a redirigir su atención hacia otras hembras luego de algunas cópulas con un mismo animal(48). Esto es una ventaja reproductiva, ya que los machos que investigan e inseminan muchas hembras, potencialmente dejan un mayor número de crías para la siguiente generación en comparación con aquellos carneros que permanecen con una sóla hembra.

En condiciones extensivas, algunos investigadores han encontrado un patrón diurno en el comportamiento sexual, observando que la mayoría de las cópulas suceden en picos, temprano por la mañana y tarde por la tarde, con poca actividad nocturna y casi nula entre las 23:00 y las 03:00 horas $(49,50)$. Además de la hora del día, otros factores involucrados son; altas temperaturas ambientales y severas pérdidas de peso, como agentes que deprimen la actividad sexual(51). Las razas originarias de climas templados se ven más afectadas que las de origen tropical durante las horas de intensa radiación(52).

Bajo condiciones controladas, Price(53) encontró que el número promedio de eyaculaciones logradas por 16 carneros expuestos ante hembras durante dos periodos de $60 \mathrm{~min}$, fluctuó entre 0.0 y 6.5 , con un coeficiente de variación equivalente a 0.54 . Esta considerable variación genética puede retribuir en grandes avances en poco tiempo al implementar programas de selección(54). Por ejemplo, Bench et al(54) encontraron diferencias significativas entre el comportamiento sexual de los hijos de carneros con alta y baja capacidad de servicio en tan sólo una generación(55). De forma similar, Kridli et al(56) demostraron la variaicón genética entre razas, al realizar una serie de cruzas y probar que los corderos Romanov x Awassi

\section{PRENATAL EFFECT ON SEXUAL BEHAVIOR}

Sexual differentiation between the male and female behavioral patterns is the result of the action of hormones in the brain during sensitive periods of fetal development. The brain in principle operates as female, and in males occurs changes related to the defeminizacion and masculinization of sexual behavior, which are the culmination of a series of exposures to testicular steroids(57).

Prenatal androgens masculinazes postnatal reproductive neuro-endocrine function and behavior of the sheep. The above is demonstrated by treatment pregnant ewes with testosterone during half of the gestation period, which masculinize sexual behavior and secretion of LH in ewe-lambs, presumably in part via aromatization and union of estrogen receptors in the brain(58).

In the ram, this defeminization of the brain occurs between 50 and $80 \mathrm{~d}$ of gestation. For this reason, in twins, those males born with a brother will have higher service capacity than those born with a sister, due to the greater amount of androgens that the first was exposed to during fetal life. In addition, the service capacity is better as the size of the litter increases(59). This implies that the males born in multiple births tend to be better sires than those from single births, coupled with the productive advantage obtained by selecting for multiple births.

The fact that the ovine sexually dimorphic nucleus is organized prenatally by exposure to testosterone, suggests that the brains of homosexual rams may be due to a subandrogenization during their development(60). This based on a previous work(26) which explains that the medial preoptic area, controls the expression of male sexual behavior, suggesting that the natural variations that occur with respect to sexual orientation, could be related to differences in brain anatomy and the capacity of synthesis of estrogen. In addition, 
poseen una mayor frequencia de monta que los Awassi y F1 Charollais x Awassi, mientras que los Awassi tuvieron mayor capacidad de monta con hembras de cola-gruesa que los Charollais x Awassi y Romanov x Awassi.

En resumen, el comportamiento de cópula es el resultado de varias unidades conductuales que abarcan la identificación de la hembra, el cortejo y la eyaculación. Este comportamiento puede verse afectado por condiciones ambientales como la dominancia o la presencia de hembras en celo entre otros. Factores que es necesario conocer por su aplicabilidad en la reproducción controlada de los ovinos, y de esa manera tener la opción de diseñar técnicas de manejo que permitan utilizar al máximo las ventajas reproductivas que puede ofrecer un semental.

\section{EFECTO PRENATAL SOBRE EL COMPORTAMIENTO SEXUAL}

La diferenciación sexual en los patrones conductuales entre el macho y la hembra es el resultado de la acción de hormonas esteroides en el cerebro durante periodos sensitivos del desarrollo fetal. El cerebro en principio opera como femenino, y en el macho, ocurren cambios relacionados con la defeminización y masculinización de las conductas sexuales, que son la culminación de una serie de exposiciones a los esteroides testiculares(57).

Los andrógenos prenatales masculinizan la función neuro-endocrina reproductiva postnatal y la conducta del ovino. Lo anterior lo demuestran tratamientos con testosterona en borregas gestantes durante la mitad de la preñez, mismos que masculinizan la conducta sexual y secreción de la LH en corderas, presumiblemente en parte vía la aromatización y unión de los receptores de estrógeno en el cerebro(58).

En el carnero, esta defeminización del cerebro ocurre entre los 50 y 80 días de gestación. Por esta razón, en partos gemelares, aquellos machos nacidos con un hermano, poseerán
Resko et al(61) support the theory that these preferences can be traced back to the fetal development and represent a phenomenon of sexual differentiation, where the differences may be a product of an atypical prenatal exposure to androgens and estrogen metabolites(62).

It is necessary to carry out further research to elucidate the mechanisms of specific action of different hormones and their effects in the brain during fetal life, which will allow us to understand how behavior and sexual orientation of these animals can be modified. The understanding of the processes of defeminization and masculinization so early, offer wide possibilities of explanation to several processes, and without a doubt, changes in management for its practical application to future practices.

\section{RAISING EFFECTS}

Although sexual behavior is typified in the genes, it has also a strong learning component. For example, animals at birth, will impront with their own species. Kendrick et al(63) mentioned that the rams raised by suckler goats will try to mount goats when they mature. However, the social affinities may disappear by a prolonged separation or after sexual experiences with his own species(64).

During childhood, the lambs play from a very early age. As part of the game, they practice sexual behavior patterns. These behaviors lack of sexual motivation but can serve to start preparing the animals for their adult lives(65). During the game, both sexes mount each other(66), males, particularly those from simple parity, tend to be more active, possibly for being more vigorous, large, heavy, and are the males generally those who mainly perform courtship behaviors, aimed higher for females(67).

As animals are developed, initially manifest a real peak of courtship and riding activity on the young rams between 4 and 6 wk of age, behavior that increases gradually until puberty, about 26 wk-old, where most of these rams exhibit this behavior. So the sexual behavior of 
mayor capacidad de servicio que aquéllos nacidos con una hermana, debido a la mayor cantidad de andrógenos a que fue expuesto el primero durante su vida fetal. Además, la capacidad de servicio se incrementa a medida que aumenta el tamaño de la camada(59). Lo anterior implica que los machos nacidos de partos múltiples tienden a ser mejores reproductores que los de partos sencillos, aunado a la ventaja productiva que se obtiene al seleccionar a favor de nacimientos múltiples.

La demostración de que el núcleo dimórfico sexual del ovino es organizado prenatalmente por exposición a la testosterona sugiere que el cerebro de los carneros homosexuales pueda deberse a una sub-androgenización durante su desarrollo(60). Esto con base en un trabajo previo(26) donde se explica que el área preóptica medial, controla la expresión de las conductas sexuales del macho, sugiriendo que las variaciones naturales que ocurren respecto a la orientación sexual, podrían estar relacionadas con diferencias en la anatomía cerebral y la capacidad de síntesis de estrógeno. Asimismo, Resko et al(61) apoyan la teoría de que estas preferencias pueden rastrearse hasta el desarrollo fetal y representar un fenómeno de diferenciación sexual, donde las diferencias quizá sean producto de una exposición prenatal atípica a los andrógenos y sus metabolitos estrogénicos(62).

Es necesario realizar mayor investigación con el fin de dilucidar los mecanismos de acción específicos de diferentes hormonas y sus efectos a nivel cerebral durante la vida fetal, que nos permitan entender cómo puede verse modificado el comportamiento y la orientación sexual de estos animales. El entendimiento de los procesos de defeminización y masculinización en edades tan tempranas, ofrecen amplias posibilidades de explicación a varios procesos, y sin duda, modificaciones en las prácticas de manejo para su aplicación práctica a futuro.

\section{EFECTOS DE CRIANZA}

Aunque la conducta sexual se encuentra tipificada en los genes, también tiene un fuerte the rams seems to develop in two phases: first, a pre-pubertal period with an intense sexual activity (game), and second, during adolescence, where the frequency of the activity is relatively minor but more similar to the sexual behavior of an adult (mount with erection).

Not all the rams have a good sexual behavior or at the same intensity. Factors such as age and breed, among others, have a fundamental role in the manifestation of the elements of sexual interest(68). This variation may be due among other factors to the artificial selection and breeding methods. The first can be exemplified when under intensive conditions, sires are traditionally chosen to giving minor importance to sexual behavior. Libido in males is not considered when their need to compete for females in heat is eliminated, since rams are individually handled for serving females (directed mounts), or they are used for collecting semen for artificial insemination. While the conception is carried out, the producer is not interested in sacrificing animals of low libido. Another common practice among producers is that during weaning, generally lambs are separated by sex. However, males must have heterosexual experiences during the period from weaning to year of age, making it easier to develop the sexual preference of rams to females (instead of to males), in addition to accelerating the emergence of sexual behavior(5). Rams without experience, who are exposed to adult females, can delay the manifestation of his normal sexual behavior for several weeks. The rams raised in groups of only males, are frequently mounted between them, but when the option of mounting a female is presented, they will prefer to do it with the latter and will maintain its heterosexual orientation. However, around $9 \%$ of the animals bred under these conditions may develop sexual orientation towards their fellow males and keep it throughout their life(69).

Tilbrook et al( 70 ) showed that the administration of $\mathrm{GnRH}$ agonists to prepubertal rams 16 wkold immediately before puberty, inhibits the 
componente aprendido. Por ejemplo, los animales al nacer, se improntan con su propia especie. Kendrick et al(63) mencionan que los carneros criados por cabras nodrizas intentarán montar cabras cuando maduren. Sin embargo, las afinidades sociales pueden desaparecer por una separación prolongada o luego de experiencias sexuales con su misma especie(64).

Durante su infancia, los corderos juegan desde edades muy tempranas. Como parte del juego practican patrones de conducta sexual. Estas conductas carecen de la motivación sexual pero pueden servir para ir preparando a los animales para su vida adulta(65). Durante el juego, ambos sexos se montan unos a otros(66), los machos, particularmente los de parto sencillo, tienden a ser más activos, posiblemente por ser más vigorosos, grandes y pesados, y son los machos en general los que realizan mayoritariamente conductas de cortejo, dirigidas en mayor proporción hacia las hembras(67).

Conforme los animales se desarrollan, inicialmente se manifiesta un pico en la actividad real de cortejo y monta en los carneros jóvenes entre las cuatro y las seis semanas de edad, comportamiento que aumenta paulatinamente hasta la pubertad, donde alrededor de las 26 semanas, la mayoría de los carneros exhiben estas conductas. Por lo que la conducta sexual de los carneros parece desarrollarse en dos fases: primero, un periodo pre-puberal de una intensa actividad de tipo sexual (juego), y segundo, durante la adolescencia, donde la frecuencia de la actividad es relativamente menor pero más parecida a la conducta sexual del adulto (montas con erección).

No todos los carneros tienen un buen comportamiento sexual ni en la misma intensidad. Factores como la edad y la raza, entre otros, tienen un rol fundamental en la manifestación de los elementos de interés sexual(68). Esta variación puede deberse entre otros factores a la selección artificial y los métodos de crianza. La primera puede ejemplificarse cuando bajo condiciones development of sexual behavior, reduced the concentrations of plasma testosterone, retards the testicular and epididymal development and reduces the growth rate. The effects on sexual behavior were reversible. However, the weight of the epididymis and testis were still reduced in rams treated, $8 \mathrm{wk}$ after the end of the experiment, suggesting that the reproductive function in rams is sensitive to the testicular hormones and gonadotropins immediately before puberty. These results demonstrate that this age period is critical for pubertal changes, and that testosterone plays an important role at the onset of puberty and sexual maturity(14).

Of the lambs raised in groups of a single sex, $50 \%$ respond sexually to ewes in heat in his first contacts with them when adults, compared with $100 \%$ of sheep raised in a similar way but with the opportunity to see, hear and smell females, though physically separated (wire mesh) from them(71). Those who do not respond, it is estimated that a 27 to $30 \%$ will become active after cohabiting with the ewes for a while, but service capacity will tend to be lower than the average of the group(72). In general, the sexual performance of virgin rams to levels comparable with the males sexually experienced, can raise after one or two brief exposures to females in estrus if they are in good body condition(71).

Stellflug and Lewis(73) found that if rams bred in groups of only males, coexisted with females in heat at an early age (7 to $8 \mathrm{mo}$ ), they will achieve higher scores on service capacty tests performed between 16 and 19 mo of age. However, one year old rams short exposures, apparently do not improve their ability to copulate(74).

This in short, makes us see the importance that some degree of exposure with the opposite sex during early life has on the reproductive development of male.

\section{MEASURING SEXUAL BEHAVIOR}

Fthenakis et al(75) after evaluating 293 rams, found that the most common problems in the 
intensivas, los reproductores tradicionalmente se escogen dando mínima importancia al comportamiento sexual. La libido de los machos no se considera cuando se elimina su necesidad de competir por hembras en celo al manejar carneros en forma individual ante las hembras (montas dirigidas), o cuando se colecta semen para inseminación artificial. Mientras la concepción se lleve a cabo, el productor no está interesado en sacrificar animales de baja libido. Otra práctica común entre los productores consiste en que durante el destete, generalmente separa a los corderos por sexos. Sin embargo, para los machos es importante tener experiencias heterosexuales durante el periodo comprendido entre el destete y el año de edad, lo que facilitará que la preferencia sexual de los carneros sea hacia hembras y no hacia machos, además de acelerar la aparición de la conducta sexual(5). Los carneros sin experiencia, que son expuestos a hembras adultas, pueden atrasar varias semanas la manifestación de su conducta sexual normal. Los carneros en grupos de sólo machos, con frecuencia se montan entre ellos, pero al presentarse la opción de una hembra, preferirán hacerlo con esta última y mantendrán su orientación heterosexual. Sin embargo, alrededor del $9 \%$ de los animales criados bajo estas condiciones pueden desarrollar orientación sexual hacia sus compañeros machos y mantenerla toda su vida(69).

Tilbrook et al(70) demostraron que la administración de agonistas de $\mathrm{GnRH}$ a carneros prepúberes de 16 semanas de edad inmediatamente antes de la pubertad, inhibe el desarrollo de la conducta sexual, reduce las concentraciones de testosterona en plasma, retarda el desarrollo testicular y del epidídimo y reduce la tasa de crecimiento. Los efectos en la conducta sexual fueron reversibles. Sin embargo, el peso del epidídimo y testículo aún eran reducidos en los carneros tratados, ocho semanas después del final del experimento, sugiriendo que la función reproductiva de los carneros es sensible a las gonadotropinas y hormonas testiculares inmediatamente antes de evaluation of libido were difficulties in erection and inability for mounting, discovering a negative association between the age of the ram and the percentage of problems.

To assess the problems in behavior, it is necessary to understand that this has two components: the motivational and execution. The first is known as libido, while the second is based on the libido together with the motor patterns that allow performing this behavior. The frequency, duration, or intensity of the majority of the male sexual behavior is possible to quantify, but doing so is measured the execution and not only libido. For example, to measure the number of ejaculations achieved in a given period of time (serviceability), not only consider the sexual motivation of the animal but his ability to run the behavioral patterns associated with mating.

An individual must have a relatively high libido to achieve a good rating in its service capacity test, but an animal with low service capacity, not necessarily lacks libido. The reason may be problems of locomotion (weak legs), pathological conditions, genital abnormalities, or lack of sexual experience. The inability to measure libido adequately is not a problem for many producers since their main interest is the execution of the sexual behavior.

In practice, there are different ways to assess the reproductive potential of a ram. Any of them should be done along with a complete evaluation of the sire (history of diseases, physical examination, and semen evaluation, among others). Evaluation tests of the sexual performance of the ram are important under particular situations. The first two which will be cited below are relevant to the evaluation of males mainly for semen collection or controlled mount to pen situations, whereas the latter provides more advantages when considering breeding under extensive conditions:

Reaction time test: is to record the time that takes to the male since it enters to the pen of 
la pubertad. Estos resultados demuestran que este periodo de edad es crítico para los cambios puberales, y que la testosterona juega un papel importante en el inicio de la pubertad y la madurez sexual(14).

De los corderos criados en grupos de un sólo sexo, el $50 \%$ responden sexualmente ante ovejas en celo en sus primeros contactos con ellas cuando adultos, en comparación con el $100 \%$ de los carneros criados de manera similar pero con la oportunidad de ver, oír y oler hembras, aunque separados físicamente (malla de alambre) de ellas(71). De los que no responden, se calcula que un 27 a $30 \%$ se tornarán roles activos luego de cohabitar con las ovejas durante algún tiempo, pero su capacidad de servicio tenderá a ser menor a la del promedio del grupo(72). En general, una o dos exposiciones breves ante hembras en estro puede elevar el desempeño sexual de carneros vírgenes a niveles comparables con los de machos sexualmente experimentados, siempre y cuando se encuentren en una buena condición corporal(71).

Stellflug y Lewis(73) encontraron que si carneros criados en grupos de sólo machos, convivían con hembras en celo a una edad temprana (siete a ocho meses), lograban calificaciones más altas en las pruebas de capacidad de servicio que se les realizaban entre los 16 y 19 meses de edad. Sin embargo, aparentemente exposiciones breves de carneros de un año de edad, no mejoran su habilidad de monta(74).

Lo anterior en suma, nos hace ver la importancia que para el correcto desarrollo reproductivo de los machos, tiene algún grado de exposición con el sexo opuesto durante su vida temprana.

\section{MIDIENDO LA CONDUCTA SEXUAL}

Fthenakis et al(75) después de evaluar 293 carneros, encontraron que los problemas más comunes en la evaluación de la libido fueron dificultades de erección e inhabilidad para la monta, descubriendo una asociación negativa evaluation, until it achieves the first ejaculation; this measure is a good estimator of the libido.

Test of satiety: considered the maximum number of services in a particular female.

Reproductive efficiency test: it is an assessment of great practical value to producers. It can be calculated from three points of view: a) The total number of pregnant ewes by a male for a restricted period of mating, b) The proportion of females in heat, inseminated at least once by the male and c) The number of mounts by ejaculates observed in a same male during a given period.

On the other hand, one of the most popular tests to predict the behavior of a sire in the field is the "service capacity test", that consist in exposing a sexually mature ram at one or more adult females over a period of time (between 15, 30 and up to $60 \mathrm{~min}$ ) under pen conditions. On some systems, only the number of ejaculations accomplished during this period is included. In other systems, his complete sexual behavior is qualified, giving points by the activities of courtship that performs, their mounts, and their ejaculates. The first will be worth from 1 to 5 points, depending on the intensity and complexity; the mounts will have a value of 5 points, and the ejaculations of 10 . At the end, the accumulated points are added and higher scores reflect the best performers $(76)$, while males with 0 points, are sexually inactive.

Females may be restraint or loose during the test. However, it is necessary to consider that while more freedom of movement, the ram will invest more time in courtship behavior, although this doesn't affect the number of ejaculates that performs regularly. However, it is very important that if the females are not restraint, they must be in estrus(77).

The rams with high score on these tests, can improve the fertility of the herd under intensive reproduction programs (78). In addition, rams with high service capacity will copulate several 
entre la edad del carnero y el porcentaje de problemas.

Para evaluar los problemas en el comportamiento, es necesario comprender que este tiene dos componentes: el motivacional y el de ejecución. El primero se conoce como libido, mientras que el segundo se basa tanto en la libido como en los patrones motores que le permiten realizar este comportamiento. La frecuencia, duración o intensidad de la mayoría de las conductas sexuales del macho son posibles de cuantificar, pero al hacerlo se mide la ejecución y no sólo la libido. Por ejemplo, al medir el número de eyaculaciones logradas en un periodo determinado de tiempo, (capacidad de servicio), no sólo consideramos la motivación sexual del animal sino su habilidad para ejecutar los patrones conductuales asociados con la cópula.

Un individuo debe tener una libido relativamente alta para lograr una buena calificación en su prueba de capacidad de servicio, pero un animal con baja capacidad de servicio, no necesariamente carece de libido. La razón puede estar en problemas de locomoción (patas débiles), condiciones patológicas, anormalidades en los genitales, o falta de experiencia sexual. La inhabilidad para medir la libido en forma adecuada no es problema para muchos productores dado que su interés principal es la ejecución de la conducta sexual.

En la práctica, existen diferentes formas de evaluar el potencial reproductivo de un carnero. Cualquiera de ellas debe realizarse junto con una evaluación completa del semental (historia de enfermedades, examen físico, evaluación de semen, entre otras). Las diferentes pruebas de evaluación del desempeño sexual del carnero tienen importancia bajo situaciones particulares. Las primeras dos que se citarán a continuación son relevantes para la evaluación de machos destinados principalmente a la colección de semen o situaciones de monta controlada a corral, mientras que la última ofrece más ventajas cuando se consideran empadres bajo condiciones extensivas: times with more females than those with low scores (79). However, a series of tests of service capacity is required (usually three) to really estimate the reproductive potential of an animal, due to many factors that can influence a single evaluation. Because of this, an alternative consists in the evaluation of groups of rams(80) instead of doing this individually, which saves time, though it involves other factors as competition between males. If you choose to make individual evaluations, these must be performed in the absence of other males, while group evaluations should be made using males of the same age, because there is a marked reduction in the number of mounts that subordinate rams performed while they are observed by the dominant male(81).

Unlike the bulls and male goats, in the rams it is not really a significant sexual stimulation when teammates see other sires mounting(82) so the common practice of stimulate by this way, it is inappropriate for the ram. Coupled with the above, Price et al(83) showed that sexual stimulation of the ram allowing interaction with females before being evaluated, do not influence the number of ejaculates obtained neither the result of the evaluation. However, one of the practices that really improves sexual performance of rams is allowing them to interact with other males who recently copulated with females(84).

Since the interaction with females does not directly causes sexual excitement, it seems unlikely that the increase in service capacity is due to the transmission of the scent of the female by those males that copulated, as originally thought, and perhaps this effect is rather related to the smell of semen at the foreskin of males(85).

The rams show similar rates of mounts and ejaculation with induced estrus females or in natural estrus, so this is not a factor used for the test in the sheep. However, it is necessary to consider, that when avoiding intercourse (with fabric covering the peri-anal region) ride, courtship behavior, and butting increase(86). 
Prueba de tiempo de reacción: consiste en registrar el tiempo que toma al macho desde que entra al corral de evaluación, hasta que logra la primera eyaculación. Esta medida es un buen estimador de la libido.

Prueba de saciedad: considera el número máximo de servicios en una hembra determinada.

Prueba de eficiencia reproductiva: es una evaluación de gran valor práctico para los productores y puede calcularse desde tres puntos de vista: a) El número total de hembras preñadas por un macho durante un periodo restringido de empadre, b) La proporción de hembras en celo, inseminadas al menos una ocasión por el macho y c) El número de montas por eyaculados, observados en un mismo macho durante un periodo determinado.

Por otra parte, una de las pruebas más populares para predecir el comportamiento de un semental en el campo, es la "Prueba de capacidad de servicio", ésta consiste en exponer al carnero sexualmente maduro ante una o varias hembras adultas durante un tiempo determinado (entre 15, 30 y hasta $60 \mathrm{~min}$ ) bajo condiciones de corral. En algunos sistemas únicamente se cuenta el número de eyaculaciones logradas durante este periodo, mientras que en otros, se califica su comportamiento sexual, otorgándole puntos por las actividades de cortejo que realiza, por sus montas, y por sus eyaculados. Los primeros valdrán de 1 a 5 puntos, según la intensidad y complejidad, las montas tendrán un valor de 5 puntos, y las eyaculaciones de 10. Al final se suman los puntos acumulados y las puntuaciones mayores reflejarán los mejores reproductores(76), mientras que los machos con 0 puntos, son sexualmente inactivos.

Las hembras pueden estar sujetas o libres durante la prueba. Sin embargo, es necesario considerar que mientras más libertad de movimiento tengan, el carnero invertirá más tiempo en conductas de cortejo, aunque esto
The elevation of the fore arm and the sniff of the ano-genital area of the ewe are considered behaviors of courtship, being a good estimator of libido, because when rams are prevented from mounting or intercourse, males with better service capacity, smell and elevate their front members more frequently $(87)$. Price et al(87) evaluated whether the service capacity of rams with sexual experience could be estimated through specific measurements of the libido when exposed to ewes in estrus under conditions that prevented intercourse. They found that frequencies of courtship behavior represented by the kicking and naso-genital contact, increased proportionately to the rate of ejaculation of rams, suggesting that the sexual potential could be estimated avoiding penetration. More, the frequency of the precopulatory behavior and the mounts decrease when the male is allowed to ejaculate, due to periods of sexual inactivity after each ejaculation.

The practical utility of the evaluation tests of males is that reflects what the ram will accomplish during the breeding season. Perkins et al(88) confirmed that the rams with high service capacity, possess a greater sexual activity, mating three times more with females, and breeding them early in the breeding season. Other(78) researchers found that sires of high service capacity impregnate twice as many ewes and engender twice as many lambs than the low service capacity rams.

The major advantages of using males with high service capacity in reproduction are obtained when a large number of ewe lambs require service daily. Under such conditions, these rams will double the number of females fertilized and engendered offspring, compared with lowcapacity rams(89).

In addition, the service capacity, as already mentioned, is a feature that tends to be inherited(90). Snowder et al(55) calculated a moderate heritability about $0.22 \pm 0.04$ with high repeatability $(0.72)$, results that suggest 
regularmente no afecta el número de eyaculados que realiza. No obstante, es muy importante que si las hembras no están sujetas, deberán estar en celo(77).

Los carneros con alta calificación en estas pruebas, pueden mejorar la fertilidad del rebaño bajo programas intensivos de reproducción(78). Además, los carneros con alta capacidad de servicio copularán más veces con un mayor número de hembras que aquéllos con bajos puntajes(79). Sin embargo, se requiere una serie de pruebas de capacidad de servicio (normalmente tres) para realmente estimar el potencial reproductivo de un animal, debido a multitud de factores que pueden influenciar una sola evaluación. Debido a esto, una alternativa consiste en la evaluación de grupos de carneros(80) en lugar de hacer esto en forma individual, lo que ahorra tiempo, aunque involucra otros factores como la competencia entre los machos. Si se opta por hacer las evaluaciones individuales, éstas deberán hacerse en ausencia de otros machos, y las grupales, considerando machos de la misma edad, ya que existe una marcada reducción del número de montas de carneros subordinados que son observados por machos dominantes(81).

A diferencia de los toros y machos cabríos, en los carneros no es realmente significativa la estimulación sexual que se puede lograr antes de ser evaluados cuando sus compañeros ven a otros carneros montando(82) por lo que la práctica común de estimular a los toros que se van a evaluar, viendo al que se está evaluando, resulta inapropiada en esta especie. Aunado a lo anterior, Price et al(83) demostraron que la estimulación sexual previa del carnero permitiéndole interactuar con hembras antes de ser evaluado, tampoco influye en el número de eyaculados obtenidos ni en el resultado de la evaluación. Sin embargo, una de las prácticas que sí mejora el desempeño sexual de los carneros es el permitirles interactuar con otros machos que recientemente copularon con hembras (84). that an evaluation of sexual performance gives us a reliable measure of the reproductive capacity of the ram and a favorable response to selection for this feature. The advantages referred show that rams with high libido and service capacity are able to impregnate more females than individuals of low capacity in a given period of time.

The strategy employed by the rams of high libido to accomplish better pregnancy rates is achieved not only with a more rapid rate of ejaculation, but also avoiding repeat matings with the same receptive female(79). However, when there is a small number of ewes in estrus every day, the rams with low service capacity behave as well as the high capacity, both in multiple and single matings. It is suggested to take advantage of these high service capacity rams, to reduce the number of males required under intense reproductive programs(89).

Coupled with the above, Stellflug et al(78) found that not only males with low service capacity, but also the presence of homosexual rams do not have an adverse impact on the overall reproductive outcome. The low service capacity rams together with homosexual males, got 81 more lambs than rams with high service capacity; however, this got it by using twice as many males. So service capacity testing should be used to select rams of high capacity, reduce the number of males with marginal capabilities, and decide on the number of sires to use.

A disadvantage of service capacity test is that sometimes it can be time consumer, so an easier test could be advantageous. One option seems to be the use of naloxone (an opioid inhibitor); this substance produces different answers in LH and possibly testosterone in males sexually active and inactive. However, the use of naloxone to predict service ability of the rams, has not given expected results so $\operatorname{far}(91,92)$, so it has no practical use. In the end, the more efficient ram is the one that fertilizes the greater number of females in the shortest possible time with the least number of mounts and 
Dado que la interacción con hembras directamente, no resulta en excitación sexual, parece poco probable que el incremento en la capacidad de servicio se deba a la transmisión del olor de la hembra por aquellos machos que copularon, como originalmente se pensó, y quizá este efecto esté más bien relacionado con el olor del semen en el prepucio de los machos(85).

Los carneros muestran tasas de monta y eyaculación similares ante hembras inducidas a celo o en estro natural, por lo que esto no es un factor en la oveja que se utilice para la prueba. Sin embargo, es necesario considerar, que cuando se evita la cópula (cubriendo con tela la región peri-anal) se incrementan montas, conductas de cortejo y topes(86).

La elevación del miembro anterior y el olfateo del área ano-genital de la oveja se consideran conductas de cortejo, siendo un buen estimador de la libido, porque cuando se impide la monta - la cópula, los machos con mejor capacidad de servicio, huelen y elevan sus miembros delanteros con mayor frecuencia(87). Price et al(87) evaluaron si la capacidad de servicio de carneros con experiencia sexual podría ser estimada a través de mediciones específicas de la libido cuando se les exponía ante borregas en celo bajo condiciones que evitaban la cópula, encontrando que las frecuencias de la conducta de cortejo representada por el pataleo y el contacto naso-genital, se incrementaban proporcionalmente en relación con la tasa de eyaculación de los carneros, sugiriendo que el potencial sexual podía estimarse evitando la penetración. Es más, la frecuencia de las conductas precopulatorias y las montas, disminuyen cuando a los machos se les permitía eyacular, debido a los periodos de inactividad sexual posteriores a cada eyaculación.

La utilidad práctica de las pruebas de evaluación de los machos, es que reflejen lo que el carnero logrará durante el empadre. Perkins et al(88) confirmaron que los carneros con alta capacidad de servicio, poseen una mayor actividad sexual, copulando con el triple de las hembras que ejaculations. The development of a practical, inexpensive, reliable test and easy application to pick these animals is the challenge.

\section{DOMINANT EFFECT}

In all social groups, there is a position or rank that individuals occupy inside the group. This has to do with the degree of dominance that an animal exerts on another. In sheep, particularly in large groups, this relationship is not linear, that is, if in the social scale the individual $A$ is on $B$ and $B$ over $C$, that does not mean that $A$ necessarily dominate $a$ C in any situation; which among other things, will depend on the scale of measurement. Regularly, to establish the social scale is recommended to collect long-term data. For example, we can observe a flock for a considerable period and see movements that cause some animals in their path in feeders and shade.

The dominance on the other hand, is something more momentary than the social range and will depend on the situation. For example an individual may be more motivated to eat (hunger) or mount (libido) when put to compete for a scarce resource such as food or females in estrus, respectively(93) in a given time and appear dominant in front of an individual superior to him in the social scale.

Some authors(29) mentioned that a practical way of measuring the dominance is precisely through competition for food or a female in heat, concluding that both orders are similar. However, other researchers have not found correspondence among the results obtained in tests when males compete for different resources(94).

The dominance is usually associated with visual stimuli, while the sexual stage is predominantly with olfactory. The first thing might be reflected by the presence of horns and the corporal size $(95,96)$, while the latter corresponds to messages primarily through pheromones. For example, the smell of the wool of the rams or other secretions, can affect the sexual behavior of other males(85). 
logran los de baja capacidad de servicio, y gestándolas más temprano en la temporada reproductiva. Otros investigadores(78) encontraron que los animales de alta capacidad de servicio preñan al doble de ovejas y engendran al doble de corderos que los de baja capacidad de servicio.

Las mayores ventajas de utilizar machos con alta capacidad de servicio en la reproducción se obtienen cuando un gran número de borregas requieren servicio diariamente. Bajo tales condiciones, estos carneros doblarán el número de hembras fecundadas y crías engendradas, en comparación con carneros de baja capacidad(89).

Además, la capacidad de servicio, como ya se mencionó, es una característica que tiende a ser heredable(90). Snowder et al(55) calcularon una heredabilidad moderada de al derredor de $0.22 \pm 0.04$ con una alta repetibilidad (0.72), resultados que sugieren que una evaluación del desempeño sexual nos brinda una medida confiable de la capacidad reproductiva del carnero y una respuesta favorable a la selección por esta característica. Las ventajas referidas demuestran que carneros con alta libido y capacidad de servicio son capaces de preñar a más hembras que los individuos de baja capacidad en un periodo de tiempo determinado.

La estrategia empleada por los carneros de alta libido para lograr mejores tasas de preñez se logra no sólo con una tasa de eyaculación más rápida, sino también evitando repetir cópulas con la misma hembra receptiva(79). Sin embargo, cuando se dispone de un número pequeño de ovejas en estro diariamente, los carneros con baja capacidad de servicio se comportan tan bien como los de alta capacidad, tanto en empadres múltimples como en sencillos, por lo que se sugiere aprovechar la ventaja que dan los carneros con alta capacidad de servicio para reducir el número de machos requeridos en programas reproductivos intensos(89).

Aunado a lo anterior, Stellflug et al(78) encontraron que no sólo los machos con baja
Dominance can be set in groups since the animals are young, remaining stable as there are no changes in the members, although it may shift as the rams get older(97). Dominance can also be established almost immediately in animals that interact for the first time.

When features as age, weight and gender among others, are similar, in general the dominance is established through fighting. However, some individuals with horns or heavy can achieve to establish its dominance without displaying aggressive behavior. So a dominant male can be integrated in a herd of females or young ones, with almost passive immediate recognition of his status(98). The body mass is a key factor(97), which explains why the sexual dimorphism in this species. Several authors $(99,100)$ agree that there is a direct relationship of the social position when there are notable differences in weight and age, but not in homogeneous groups $(45,101)$.

In young animals, Ungerfeld and GonzalezPensado(45) found that the hierarchy affects the reproductive development. The heavier lambs tend to have higher social rank, grow faster, gain more weight, and increase the testicular size, producing spermatozoa and sexual behavior earlier. However, nor the amount of sexual play, or prematurity puberty are related to the service capacity of the rams when adults $(67,102)$.

On the other hand, the courtship in the rams may differ according to the social status that show when lambs, although there is no clear effects on other semen features(102) or sexual behavior. Actually, very few is known about the effects of the social rank in the reproductive development of prepubertal lambs. However, some researchers(45) observed that up to 38 wk of age, the lambs of highest social scale matured sooner than those located low on the scale, evident maturity showed by greater increases in body weight, scrotal circumference, semen production and sexual behavior directed toward females. 
capacidad de servicio, sino que tampoco la presencia de carneros homosexuales tienen un impacto adverso en el resultado reproductivo general. Los machos de baja capacidad de servicio y homosexuales juntos, engendraron 81 corderos más que los que lograron los carneros con alta capacidad de servicio; sin embargo, esto lo consiguieron empleando el doble de machos. Por lo que las pruebas de capacidad de servicio deben usarse para seleccionar carneros de alta capacidad, reducir el número de machos con capacidades marginales y decidir sobre el número de machos a utilizar.

Una desventaja de la prueba de capacidad de servicio, es que en ocasiones puede resultar impráctica, por lo que una prueba más sencilla, podría ser ventajosa. Una opción parece ser la naloxona (un inhibidor de los opioides); esta sustancia produce respuestas diferentes en la LH y posiblemente testosterona de machos sexualmente activos e inactivos. Sin embargo, el uso de naloxona para predecir la capacidad de servicio de los carneros, hasta ahora no ha dado los resultados esperados $(91,92)$, por lo que carece de utilidad práctica.

Al fin de cuentas, el carnero más eficiente es aquél que preña al mayor número de hembras en el menor tiempo posible con el menor número de montas y eyaculaciones. El desarrollo de una prueba práctica, barata, confiable y de fácil aplicación para escoger estos animales, es el reto.

\section{EFECTO DE DOMINANCIA}

En todo grupo social existe una posición o rango que ocupan los individuos que la conforman. Esta tiene que ver con el grado de dominancia que un animal ejerce sobre otro. En los ovinos, particularmente en grupos grandes, esta relación no es lineal, es decir, si en la escala social el individuo A está sobre $B$ y $B$ sobre $C$, eso no quiere decir que $A$ necesariamente dominará a $\mathrm{C}$ en toda situación. Lo que entre otras cosas dependerá de la escala de medición. Regularmente
During adult life, when more than one ram is used to service a flock (multiple matings), there is a clear effect of dominance(103), where even dominant males may inhibit the sexual behavior of animals subordinated by their mere presence (81), to what is called "audience effect". At the same time, the presence of subordinate rams stimulates the sexual activity of the midrange(104) and high ones(105), increasing the number of mounts and ejaculates performed by these rams.

The sexual experience(97), small areas and few ewes in heat available daily $(98,106)$, are other factors in addition to the mentioned (weight, age, size and horns), that affect the intensity of the dominance effect. The dominant ram copulate with the majority of the females of the flock by subjecting to other adult rams and all youngs(107), thus engendering the majority of calves(108). According to Hulet(109), a dominant male can mate 12 to 15 times per day during the breeding season, while subordinates rams average between two and five daily copulations.

Submissive rams under the presence of dominants in extensive conditions mounted fewer females, less often, and most of the copulations occur with less attractive females(110), and at a time where fertilization is less likely to occur (after ovulation). J ewell et al(111) found that rams which copulate between 9 and $15 \mathrm{~h}$ after estrus started, have higher probabilities to gestate females, since this is the most fertile moment, and it is during this time that dominant males remain rounding these females, avoiding the copulations of subordinates(112). However, when late copulations occur, the submissive male extract up to $50 \%$ of the semen previously existing in the vagina of females recently covered(113), in an attempt to increase the chances of their sperm to fertilize. In addition, the rams under situations of competition by a female, develop opportunistic strategies, for example, Dimas et al(105) found that the sperm concentration increased when collecting semen from rams in 
para establecer la escala social se recomienda colectar datos a largo plazo. Por ejemplo, podemos observar un rebaño y ver los desplazamientos que provocan algunos animales a su paso, en los comederos y sombreaderos durante un periodo considerable de tiempo.

La dominancia por otra parte, es algo más momentáneo que el rango social y dependerá de la situación. Por ejemplo un individuo puede estar más motivado a comer (hambre) o a montar (libido) cuando se le pone a competir por un recurso escaso como puede ser comida o hembras en celo, respectivamente(93) en un momento determinado, y aparecer dominante ante un individuo superior a él en la escala social.

Algunos autores(29) mencionan que una forma práctica de medir la dominancia es precisamente a través de la competencia por alimento o por una hembra en celo, concluyendo que ambos órdenes son similares. Sin embargo, otros investigadors, no han encontrado correspondencia entre los resultados obtenidos en pruebas cuando los machos compiten por diferentes recursos(94).

La dominancia generalmente está asociada con estímulos visuales, mientras que el estado sexual lo está preponderantemente con olfatorias. Lo primero puede verse reflejado en la presencia de cuernos y el tamaño corporal $(95,96)$, mientras que lo segundo corresponde a mensajes fundamentalmente a través de feromonas. Por ejemplo, el olor de la lana de los carneros u otras secreciones, puede afectar el comportamiento sexual de otros machos(85).

La dominancia puede establecerse en grupos desde que los animales son jóvenes, permaneciendo estables mientras no haya cambios en los miembros que lo integran, aunque éstas puede cambiar conforme los carneros envejecen(97). También pueden establecerse casi de inmediato en animales que interactúan por primera vez.

Cuando las características de edad, peso y sexo entre otras, son similares, por lo general la the presence of another male, regardless of the hierarchy of the rams present or collected. Additionally, males of low status can have a copulatory rate higher than rams of high social rank, when they don't have to compete for females(45). As sexual dominance does not correlate with fertility, a dominant male infertile, could be disastrous in multiple matings.

Fowler and Jenkins(94) showed that the pregnancy rate of the flock is associated with the social position that occupy the lower fertility rams. When the infertile ram is the dominant, the pregnancy rate decreases. On the contrary, when the ram of higher hierarchy is fertile and the subordinates are sub fertile or infertile, flock fertility is not affected. Castrillejo(114) mentions that using at least $3 \%$ of males from the total number of ewes to cover, is an empirical ratio with which it is assumed that sub-fertile or sterile males will be offset by the services of those who are not.

In short, information in particular on the influence of the social rank in the prepubertal of sexual behavior development is scarce, so it is necessary to develop further research in this area. As well as in the study of strategies that subordinate animals use in their attempt to transfer their genes to future generations and the mechanisms involved in the reproductive process, and how these are affected by situations of the dominance-submission relationship.

\section{SELECTION OF SEXUAL COMPANION}

Rams copulate with the same intensity when they have the opportunity of choosing between subject ovariectomized female, treated or not with estrogen(115); they do not discriminate between ewes in natural estrus and those ovariectomized treated with progesterone and estrogen(116). The attractiveness that can exert a female to the ram is not related to estrogen levels used to induce her estrus. This is characteristic of each individual, and is not associated with the soliciting behavior of the 
dominancia se establece mediante combates. Sin embargo, algunos individuos grandes o con cuernos pueden lograr establecer su dominancia sin mostrar comportamiento agresivo. Por lo que un macho dominante puede integrarse en un rebaño de hembras o jóvenes, con reconocimiento inmediato casi pasivo de su estatus(98). La masa corporal es un factor determinante( $(97)$, lo que explica el porqué del dimorfismo sexual de esta especie. Varios autores $(99,100)$ concuerdan que existe una relación directa con la posición social cuando hay diferencias notables en peso y edad, más no en gupos homogéneos $(45,101)$.

En los animales jóvenes, Ungerfeld y GonzálezPensado(45) encontraron que la jerarquía afecta el desarrollo reproductivo. Los corderos más pesados, tienden a tener mayor rango social, crecen más rápido, ganan más peso, e incrementan el tamaño testicular, produciendo espermatozoides y conductas sexuales más precozmente. Sin embargo, ni la cantidad de juego sexual, ni la precocidad a la pubertad están relacionadas con la capacidad de servicio de los carneros cuando adultos $(67,102)$.

Por otro lado, el cortejo en los carneros puede diferir de acuerdo con el status social que muestran cuando corderos, aunque no existen efectos claros en otras conductas sexuales o características del semen(102). En realidad, poco es lo que se sabe sobre los efectos del rango social en el desarrollo reproductivo prepuberal de los corderos. No obstante, Ungerfeld y González-Pensado(45) observaron que hasta las 38 semanas de edad, los corderos de más alta escala social maduraron más pronto que aquéllos ubicados bajos en la escala, madurez manifiesta en mayores incrementos de peso corporal, circunferencia escrotal, producción de semen y conducta sexual dirigida hacia hembras.

Durante la vida adulta, cuando más de un carnero se utiliza para dar servicio a un rebaño (empadres múltiples), existe un claro efecto de dominancia(103), donde incluso los machos dominantes pueden inhibir el comportamiento female(117). However, ewes which apply intravaginal antibiotic treatments, are less attractive, so it is considered that the vaginal flora increase the attractiveness of the sheep(118). Similarly, the use of intravaginal sponges treatments reduces the attractiveness of females, which could be linked also to the alteration of the vaginal flora $(119,120)$.

On the other hand, the attractiveness of females is constant from one cycle to another and depends (on some breeds at least) partly, from the presence of wool, as rams prefer to copulate ewes with wool in comparison of those recently shorn(121). However, the preference for sheep wool has only been observed in extensive conditions and not in pens(122).

Rams also prefer, mature compared to young females, and choose to mate with females that have not copulated(123), although perhaps in an effort to pass on their genes, the situation is different when they are faced with females that have been mounted by another male. Lezama et al(85) found that when depositing semen on the vulva, coming from a ram other than which they were evaluating, the interval between ejaculates is reduced, situation that it was not possible to observe when the same ram semen was deposited.

Males prefer to mate with females of the same breed of their mother or step-mother (who raised them in case of adoption), or those who are similar to them, but not too similar, in an apparent behavior against inbreeding, avoiding the spread of the same genetic material $(124,125)$. Since the rams are not able to differentiate among female sheep (daughters) genetically related from those who are not; in a study conducted recently by Orihuela and Vazquez(126) with Santa Cruz animals, they found that the rams mount without distinction to both types of ewes. The rams also directed its preferences towards ewe lambs with best body condition, which indirectly would offer better chances of reproductive success(127). 
sexual de los animales subordinados por su sola presencia(81), a lo que se denomina "efecto de audiencia". Al mismo tiempo, la presencia de carneros subordinados estimula la actividad sexual de los de rango medio(104) y alto(105), incrementando en estos el número de montas y eyculados que efectúan.

La experiencia sexual(97), superficies pequeñas y pocas ovejas en celo disponibles diariamente $(98,106)$, son otros factores que aunados a los antes mencionados (peso, edad, tamaño y cuernos) afectan la intensidad de los efectos de la dominancia.

El carnero dominante copula con la mayoría de las hembras del rebaño sometiendo a otros carneros adultos y a todos los jóvenes(107), engendrando así a la mayor parte de las crías(108). De acuerdo con Hulet(109), un macho dominante puede copular entre 12 y 15 veces por día durante la temporada reproductiva, mientras que los subordinados promedian entre dos y cinco cópulas diarias.

Los carneros sumisos bajo la presencia de los dominantes en condiciones extensivas montan menos hembras, en menos ocasiones, y la mayoría de las cópulas ocurren con las hembras menos atractivas(110), y en momentos donde la fertilización es menos probable (después de la ovulación). J ewell et al(111) encontraron que los carneros que copulan entre las 9 y $15 \mathrm{~h}$ de iniciado el celo, tienen mayores probabilidaders de gestar hembras, ya que éste es el momento más fértil, por lo que es durante este tiempo que los machos dominantes permanecen en derredor de estas hembras, evitando las cópulas de los subordinados(112). Sin embargo, al realizar cópulas tardías, el macho sumiso extrae hasta el $50 \%$ del semen previamente existente en la vagina de hembras recientemente cubiertas(113), en un intento de incrementar las posibilidades de sus espermatozoides para fecundar. Aunado a lo anterior, los carneros bajo situaciones de competencia por una hembra, desarrollan estrategias oportunistas, por ejemplo, Dimas et al(105) encontraron que la
In general, males compete for reproductive opportunities with females, while these latest will choose among potential males. However, when the male's reproductive rate is poor or the ewe vary widely in their "quality", the selection for the male may also occur.

Some authors mention that some females may have preferences for those males that display greater intensity and complexity in their courtship behaviors. In some cases several females remain near a same male, integrating an harem, where participating females acquire a dynamic position, exchanging between groups, so that they can be mounted up to ten different rams in the same day(128). In an experiment where one male in each corner of a triangular pasture was attached, it was found that $80 \%$ of females had three or more services, and they actively sought more than one male to get them, establishing a directly proportional relationship between the number of copulations received by a female and the number of rams involved(129). This promiscuous behavior would serve to minimize the possible presence of an infertile or subfertil male and to promote pregnancy.

The preference for sexual partners of the same sex happens in a few species, such is the case as already mentioned, in certain proportion of rams. However, the explanation of why this occurs is still in debate and based among other things, on certain differences with the heterosexual rams from the neuro-biologic and physiological point of view(62), as it was explained.

In general, the sexual partner preferences seem to have a tendency to favor the reproduction of certain individuals, especially under extensive conditions. However, today the intensive rearing systems where controlled mating and artificial insemination are used, make these mechanisms aside, and the man is who selects the sires, the number of copulations and sometimes even the number of spermatozoa. 
concentración espermática aumentaba al colectar semen de carneros en presencia de otro macho, independientemente de la jerarquía de los carneros colectados o presentes. Se ha demostrado que los machos de bajo rango social pueden tener una tasa copulatoria más elevada que la de carneros de alto rango social, cuando no tienen que competir por hembras con estos últimos(45). La dominancia sexual no se correlaciona con fertilidad, por lo que un macho dominante infértil, podría ser desastroso en empadres múltiples.

Fowler y Jenkins(94) demostraron que la tasa de preñez del rebaño está asociada con la posición social que ocupan los carneros de menor fertilidad. Cuando el carnero infértil es el dominante, la tasa de preñez disminuye. Por el contrario, cuando el carnero de mayor jerarquía es fértil y los subordinados son sub fértiles o infértiles, la fertilidad del rebaño no se ve afectada. Castrillejo(114) menciona que utilizar al menos el $3 \%$ de machos del número total de borregas a cubrir, es una proporción empírica, con la que se asume que los machos sub-fértiles o estériles serán contrarrestados por los servicios de quienes no lo son.

En resumen, es poca la información existente en particular sobre la influencia del rango social en el desarrollo prepuberal del comportamiento sexual, por lo que es necesario desarrollar mayor investigación en esta área. Así como en el estudio de las estrategias que utilizan animales subordinados en su intento por transferir sus genes a generaciones futuras y los mecanismos involucrados en los procesos reproductivos, y cómo estos se ven afectados por situaciones de la relación dominanica-sumisión.

\section{SELECCIÓN DEL COMPAÑERO DE MONTA}

Los carneros copulan con la misma intensidad cuando se les da la oportunidad de escoger entre hembras ovariectomizadas sujetas, tratadas o no con estrógenos(115), tampoco discriminan entre ovejas en celo natural y hembras ovariectomizadas tratadas con

\section{MALE EFFECT}

This work is not intended to make an exhaustive review about the effect that the introduction of the males has in the reproduction of females, for this, reviews of Rosa and Bryant(130) and Ungerfeld et al(131) are recommended. What is being sought is to analyze the ram as a generator factor of the "male effect".

Scent of the wool of the sheep, and other secretions, long been known that can induce estrus in anestric ewes(21), however, in some breeds, notably in those originating in temperate climates, the male activity and synthesis of pheromones in the summer, may be insufficient to stimulate ovulation in females(130). However, we now know that the magnitude of the stimulus affects the response in females, and in addition to this, the behavior of the male contributes to the resumption of ovarian activity in sheep. This last suggests that those males that show greater sexual activity, become a better stimulus(132).

Perkins and Fitzgerald(133) showed higher percentages of females to ovulate ( $95 \%$ ) when exposed to high serving capacity rams, compared to the males of low capacity (78 \%), and these ewes in addition, showed early elevations of progesterone without estrous manifestation.

The novelty of the stimulus turns out to be an important factor. When males and females are isolated from one another before interact, best results are obtained; although the male effect can be achieved in individuals that they cohabit in adjacent pens, as long as the physical interaction is avoided(134). Therefore, certain habituation to the stimulus seems to exist, same manifested to vary while the female is exposed to the male. Ekiz et al(135) found that if ewes are intermittently exposed to rams, has more success, compared to a permanent exhibition. However, the latter causes a more synchronized distribution of services and lambing.

The strategy to reduce habituation and achieve the advantages of continuous exposure, are 
progesterona y estrógenos(116). La atractividad que puede ejercer una hembra hacia el carnero, no está relacionada tampoco con los niveles de estrógeno utilizados para inducir su celo. Esta, es característica de cada individuo y tampoco está asociada con las conductas de solicitud por parte de la hembra(117). Sin embargo, ovejas a las que se les aplican tratamientos intra-vaginales con base de antibióticos, son menos atractivas, por lo que se considera que la flora vaginal incrementa la atractividad de las ovejas(118). De la misma manera, el uso de tratamientos con esponjas intravaginales disminuye la atractividad de las hembras, lo que podría estar vinculado también a la alteración de la flora vaginal $(119,120)$.

Por otra parte, la atractividad de las hembras es constante de un celo a otro y en algunas razas depende al menos en parte, de la presencia de lana, ya que los carneros prefieren montar ovejas con lana en comparación de aquéllas recientemente trasquiladas(121). Sin embargo, la preferencia por ovejas con lana sólo se ha observado en condiciones extensivas y no en corral(122).

Los carneros además prefieren, o son acaparados por hembras maduras en comparación de las jóvenes, y escogen copular con hembras con las que no han copulado(123), aunque quizás en un esfuerzo por transmitir sus genes, la situación es diferente cuando se encuentran ante hembras que han sido montadas por otros machos. Lezama et al(85) encontraron que al depositar semen en la vulva, proveniente de un carnero diferente al que estaban evaluando, el intervalo entre eyaculados se redujo, situación que no fue posible observar cuando se depositó semen del mismo carnero.

Los machos prefieren copular con hembras de la misma raza que su madre o madrastra (quien los crió en caso de ser adoptados), o aquéllas que son similares a ellos, pero no demasiado similares, en un aparente comportamiento contra la endogamia, evitando la propagación del mismo material genético $(124,125)$ ya que los accomplished by exchanging males during this period, a situation which also increases mounting activity(136), and more copulations during the first $17 \mathrm{~d}$ of mating, that bring as a consequence an increase in the conception rate and supports possibilities for inducing twin pregnancies(137). Repeated exposure to rams for short periods, works very well when used during the transition to the reproductive season, synchronizing the distribution of services during the latter(138).

This effect, along with exogenous hormonal methods, could be an advantage. For example, the introduction of vasectomized rams simultaneously with the application of a second injection of prostaglandin F2 alpha, advances the start of the cycles and increases the number of sheep that respond to treatment(139). On the other hand, the use of melatonin in rams before placing them with ewes in anestrous increases the proportion of females to ovulate in response to the introduction of the male. Probably due to increased sexual activity of males, who also tend to be affected in some way by photoperiod, coupled with a possible increase in the secretion of some pheromones. Once in contact with the ewes, these exert a feedback on the ram, showing an increase in the $\mathrm{LH}$ and testosterone concentration, which begins approximately $12 \mathrm{~h}$ after contact between both sexes, and maintained while there are females in heat and copulations are allowed(140).

The age of the male is another factor to consider. Adult males elicit better reproductive responses in anestrous ewes, producing higher ovulation rates, estrous response, and conception rates. This difference in stimulation is explained at least in part, by different signals produced in the wool of adult rams. Conversely, the lower pregnancy rate obtained by using young rams is explained by the lower number of copulations that these animals accomplish $(141,142)$. The recent sexual experience of the ram seems to have very little or no effect(143).

A novel possibility of the male effect application is the use of less seasonal breeds of rams to 
carneros no son capaces de diferenciar entre hembras genéticamente relacionadas con ellos (hijas) de ovejas que no lo son, luego de que en un estudio realizado recientemente por Orihuela y Vázquez(126) con animales Santa Cruz, encontraron que los carneros montaban indistintamente a ambos tipos de ovejas.

Los carneros además dirigen sus preferencias hacia borregas con mejor condición corporal, lo que indirectamente ofrecería mejores posibilidades de éxito reproductivo(127).

En lo general, los machos compiten por oportunidades reproductivas con las hembras, mientras que estas últimas eligirán entre los potenciales machos. Sin embargo, cuando la tasa reproductiva de los machos es pobre o cuando las ovejas varían ampliamente en su "calidad", la selección por el macho también puede ocurrir.

Algunos autores mencionan que ciertas hembras pueden tener preferencias por aquellos machos que despliegan mayor intensidad y complejidad en sus conductas de cortejo. En algunas ocasiones varias hembras permanecen cerca de un mismo macho integrando un harem, donde las hembras participantes adquieren una posición dinámica intercambiándose entre grupos de manera que pueden ser montadas hasta por diez diferentes carneros en un mismo día(128). En un experimento donde se ató un macho en cada vértice de un potrero triangular, se encontró que el $80 \%$ de las hembras recibió tres o más servicios, y buscaron activamente a más de un macho para conseguirlos, estableciéndose una relación directamente proporcional entre el número de cópulas en que participa una hembra y el número de carneros involucrados (129). Este comportamiento promiscuo serviría para minimizar la posible presencia de un macho infértil o subfertil y favorecer la preñez.

La preferencia por compañeros sexuales del mismo sexo, sucede en pocas especies, tal es el caso como ya se mencionó, de cierta stimulate females in anestrus of more seasonal breeds(144), this allows saving in the use of artificial photoperiod or melatonin implants for sexually activate rams $(145,146)$. In addition, in tropical regions, or transitional temperate climates, there is the possibility of using hair breeds rams, who suffer little or no season effect $(130,147,148)$, to stimulate ewe breeds with more pronounced reproductive seasons. Clemente et al(149) found that Santa Cruz rams induced oestrus, conception and pregnancy in Suffolk anestric ewes while Suffolk rams only caused silent ovulations in ewes of their same breed (at $\left.19^{\circ} \mathrm{N}\right)$. This is explained at least in part, due to the difference in the magnitude of courtship behavior emitted by both breeds during the long days season(52).

The male effect is a very common technique among the sheep breeders, which has been used for several years. However, today research is going on regarding this and new possible applications as its use in combination with other treatments such as hormones or photoperiod $(150,151)$, or its use in lactating ewes(152-154).

\section{SEMEN COLLECTION}

The semen collection by means of artificial vagina requires conditioning of rams to mount and ejaculate in response to a motionless female or a mannequin. Some training techniques for sheep semen collection by artificial vagina, using as stimulus inanimate objects are found in the work of Aguirre et al(155).

Unlike bulls and bucks, who before the collection are sexually stimulated in order to obtain greater and better ejaculates through observe mounting of other males, in the rams this technique does not work ${ }^{(69)}$, so sometimes what is recommended is the introduction of a new female when a ram does not display a normal sexual arousal.

In an attempt to keep high libido in males during semen collection, Lezama et al(156) changed the female stimulation after each 
proporción de carneros. Sin embargo, la explicación de por qué se da esto, aunque aún en debate se basa entre otras cosas en ciertas diferencias de los carneros heterosexuales desde el punto de vista neuro-biológco y fisiológico(62), como ya fue explicado.

En lo general, las preferencias por el compañero sexual, parecen tener una tendencia hacia favorecer la reproducción de ciertos individuos, sobre todo bajo condiciones extensivas. Sin embargo, hoy en día los sistemas intensivos de crianza donde se utilizan montas controladas e inseminación artificial, hacen a un lado estos mecanismos, y es el hombre quien selecciona a los reproductores, el número de cópulas y en ocasiones hasta el número de espermatozoides.

\section{EFECTO MACHO}

Este trabajo no pretende hacer una revision ehaustiva sobre el efecto que tiene la introducción de los machos en la reproducción de las hembras, para esto se recomiendan las revisiones de Rosa y Bryant(130) y la de Ungerfeld et al(131). Lo que se busca es analizar al carnero como un factor generador del "efecto macho".

Desde hace tiempo se conoce que el olor de la lana de los carneros y otras secreciones, pueden inducir el celo en borregas anéstricas(21), Sin embargo, en algunas razas, particularmente en aquellas originarias de climas templados, la actividad del macho y síntesis de feromonas durante el verano, pueden ser insuficientes para estimular la ovulación en las hembras(130). No obstante, ahora sabemos que la magnitud del estímulo afecta la respuesta en las hembras, y que aunado a éste, el comportamiento del macho coadyuva a generar el reinicio de la actividad ovárica en las ovejas. Esto último sugiere que aquellos machos que muestran mayor actividad sexual, se convierten en un mejor estímulo(132).

Perkins y Fitzgerald(133) demostraron que mayores porcentajes de hembras ovulan (95\%) al ser expuestas ante carneros de alta capacidad ejaculation of the male. However, although it is possible to obtain more ejaculates from the rams, this practice does not improve the seminal characteristics or the interval between ejaculates. Apparently since it takes more than one ejaculate per female (certain sexual satiation) for this change of female stimulation can be seen reflected in the restoration of libido and sperm of the ram, as shown in the goat $(157,158)$.

Other practices commonly used in other semen collection ruminants as to prevent physical contact with the stimulus animal after the first ejaculation, also proved to have no effect on the rams(156). A variant of the use of the artificial vagina is a device that is placed into the vagina of the ewe, and recovered once the ram ejaculate in it. It has the advantage of not requiring males trained to tolerate the presence of the human and his contact to their genitals for guiding the penis into the artificial vagina(159).

A technique of semen collection, used in those males who have not been trained to work with an artificial vagina, with legs, spine, or lack of libido problems, is the electro-ejaculation. However, this technique should be avoided, since it can transmit defects to their offspring, which are not observed during the collection process, such as failure or lack of sexual interest, weakness of legs, erectile dysfunction, among others. In addition, the electro-ejaculation not always culminates in the production of an ejaculate; these are of lesser quality and induces stress in animals(160), generating considerations concerning the welfare of the same. It has been shown that during electro-ejaculation, the electricity applied induces important changes in heart rate and levels of cortisol(161), so it has been banned in some countries(162). If its application is indispensable, it is imperative to associate it with any anesthetic treatment to reduce stress effects(163).

Artificial insemination is a widespread technique, especially in countries with a sheep production 
de servicio, en comparación con las expuestas a machos de baja capacidad (78 \%), y estas ovejas además muestran elevaciones de progesterona tempranas sin manifestación de celo.

La novedad del estímulo resulta ser un factor importante. Cuando hembras y machos se encuentran aislados unos de otros antes de interactuar, se obtienen mejores resultados, aunque el efecto macho puede lograrse en individuos que cohabitan en corrales adyacentes, siempre y cuando se evite la interacción física(134). Por lo anterior, pareciera existir cierta habituación al estímulo, misma que se manifiesta al variar el tiempo que se expone la hembra al macho. Ekiz et al(135) encontraron que si las borregas se exponen a carneros en forma intermitente, se tiene más éxito, en comparación con una exposición permanente. Sin embargo, esta última provoca una distribución de los servicios y partos más sincronizada.

La estrategia para reducir la habituación y lograr las ventajas de una exposición contínua, se logran intercambiando machos durante este periodo, situación que además incrementa la actividad de monta(136), y mayor cantidad de cópulas durante los primeros 17 días de empadre, que traen como consecuencia un aumento de la tasa de concepción y favorece las posibilidades de inducir gestaciones gemelares(137). La exposición repetida a carneros por periodos cortos, funciona muy bien cuando se utiliza durante la transición hacia la temporada reproductiva, sincronizando la distribución de los servicios durante esta última(138).

También se puede aprovechar este efecto junto con métodos hormonales exógenos. Por ejemplo, la introducción de carneros vasectomizados simultáneamente con la aplicación de una segunda inyección de prostaglandina F2 alfa, adelanta el inicio de los celos e incrementa el número de ovejas que responden al tratamiento(139). Por otra parte, el uso de melatonina en carneros antes de tradition, and offering great benefits especially in genetics. The most widespread technique for semen collection for this purpose is the use of the artificial vagina, and today research continues to know how behavioral factors affect the performance of rams intended for this purpose. Factors such as the frequency of ejaculation, abstinence $(147,164)$ or its relationship with the libido and ontogeny(165).

\section{SEASONALITY}

In most breeds, rams are seasonal and show greater libido during short days, coinciding with the resumption of ovarian activity in the female ${ }^{(3)}$. This reproductive rhythm is controlled by the photoperiod(166). The retina of the eye captures the day light and transmits the information via the optic nerve to the suprachiasmatic nucleus, paraventricular nucleus and the spinal cord, where nerves emerge to the pineal gland, where nervous stimulation becomes a hormonal stimulation, secreting melatonin during the hours of darkness. Melatonin in the ram (short day breeders) is able to stimulate the release of gonadotropins releasing hormone $(\mathrm{Gn}-\mathrm{RH})$ in the anterior hypothalamus, promoting the secretion of gonadotropins and gonadal activity $(167,168)$.

In the male reproductive system of other species(169) melatonin receptors, have been located so it has been proposed that this hormone is capable of modulating the morphology of seminiferous tubules(170), the Leydig cells(171) and thus the secretion of testosterone(169). There are also melatonin receptors in the epididymis(172), prostate $(173,174)$ and the sperms itself(175).

Thyroid hormones are also an important component in the seasonality. The removal of the thyroid gland ends with seasonal patterns in reproductive activity(176). The breeds originating in middle or high latitudes temperateclimates are seasonal animals(177). However, results on the effect of photoperiod in the hair breed rams are variable. In tropical and 
introducirlos ante ovejas en anestro estacional, incrementa la proporción de hembras que ovulan en respuesta a la introducción del macho, seguramente debido a una mayor actividad sexual de los machos, quienes también suelen verse afectados en cierta forma por el fotoperiodo, aunado a un posible aumento en la secreción de algunas feromonas. Una vez en contacto con las ovejas, éstas ejercen una retroalimentación en el carnero, mostrando un incremento en la concentración de $\mathrm{LH}$ y testosterona que inicia aproximadamente $12 \mathrm{~h}$ después del contacto entre ambos sexos, y se mantienen mientras existan hembras en celo y se permitan las cópulas(140).

La edad del macho es otro factor a considerar. Los machos adultos producen mejores respuestas reproductivas de las ovejas en anestro en comparación con carneros jóvenes, provocando mayores porcentajes de ovulación, respuesta estral y tasas de concepción. Esta diferencia en la estimulación se explica al menos en parte, por las distintas señales emitidas en la lana que producen los carneros adultos. Por el contrario, la menor tasa de preñez obtenida al usar carneros jóvenes se explica por el menor número de cópulas que estos animales proporcionan $(141,142)$. La experienecia sexual reciente del carnero parece tener muy poco 0 nulo efecto(143).

Una posibilidad novedosa de aplicación del efecto macho es el uso de carneros de razas menos estacionales para estimular hembras en anestro de razas más estacionales(144), esto permite ahorro en el uso de implantes de melatonina o del fotoperiodo artificial para activar sexualmente a los machos $(145,146)$. Además, en las regiones tropicales o de transición hacia climas templados, existe la posibilidad de usar carneros de razas de pelo, quienes sufren poco o nulo efecto estacional(130, 147,148), para estimular borregas de razas con temporadas reproductivas más marcadas. Clemente et al(149) encontraron que carneros Santa Cruz indujeron estro, concepción y preñez en borregas Suffolk anéstricas en comparación subtropical environments some breeds may be very little or not affected by seasonal variations in day light hours(178) or temperature $(76,179)$, but by changes in the provision of feed during the year(180).

Handling changes of day light hours in a controlled way, shows great variation among breeds. For example, El-Alamy et al(181) obtained near twice ejaculations in Finn than in Dorset rams. In addition, this difference in libido was associated with higher sperm concentrations in the Finn sheep. Apparently, the changes in the photoperiod did not affect the sperm concentration in the Finn sheep. Hormonally, $16 \mathrm{~h}$ light produced increases in the prolactin levels of both breeds, but particularly higher in the Finn sheep, although the levels of testosterone in both breeds were not affected.

The general consensus is that males are less affected than females by photoperiod, and although decreased, preserve its fertilizing capacity throughout the year(130). Likewise, there are variations among individuals. The latter may be due at least in part to the seasonal reproduction and the endocrine mechanisms involved may be affected by incentives behavior that emerge from the social relations that animals establish with others of the same species. For example, Aguirre et al(182) showed that the magnitude of the seasonal effect was not enough to avoid that the rams could be used for breeding throughout the year. However, males can be affected differently, depending on its hierarchy in the flock. The dominant rams are mostly influenced by photoperiod, decreasing their reaction times, increasing the concentration of testosterone and producing greater amount of sperm per ejaculate than submissive males during the autumn and winter months. Another factor identified by the same authors(147), was the frequency of collection. The rams undergoing high rates of collection showed increased libido and testosterone levels in short days that rams undergoing lower collection rates.

Among the breeds originating in temperate climates, the more seasonal, are the Suffolk, 
con carneros Suffolk, quienes sólo provocaron ovulaciones silentes en borregas de su misma raza a una latitud de $19^{\circ} \mathrm{N}$. Lo anterior se explica al menos en parte, debido a la diferencia en la magnitud de conductas de cortejo emitidas por ambas razas de carneros(52) durante la temporada de días largos.

El efecto macho es una técnica muy socorrida entre los ovinocultores, que se ha venido utilizando por varios años. Sin embargo, hoy en día se sigue investigando al respecto y surgen nuevas posibles aplicaciones como su uso en combinación con otros tratamientos como hormonas o fotoperiodo $(150,151)$, o su aplicción en ovejas lactantes(152-154).

\section{COLECCIÓN DE SEMEN}

La colección de semen mediante vagina artificial requiere del condicionamiento de los carneros para montar y eyacular en respuesta a una hembra inmóvil o a un maniquí. Algunas técnicas de entrenamiento de carneros para colección de semen mediante vagina artificial, utilizando como estímulo objetos inanimados se encuentran en el trabajo de Aguirre et al(155).

A diferencia de toros y machos cabríos, quienes antes de la colecta son estimulados sexualmente con el fin de obtener mayores y mejores eyaculados a través de observar las montas de otros machos, en los carneros esta técnica no funciona(69), por lo que en ocasiones lo que se recomienda es la introducción de una nueva hembra cuando un carnero no muestra una excitación sexual normal.

En un intento por mantener alta la libido de machos durante la colección de semen, Lezama et al(156) cambiaban la hembra estímulo después de cada eyaculado del macho. Sin embargo, aunque es posible obtener más eyaculados de los carneros, esta práctica no mejora las características seminales ni el intervalo entre eyaculados. Aparentemente debido a que se requiere más de un eyaculado por hembra (cierto saciamiento sexual) para que este cambio de hembra estímulo se pueda
Hampshire and Columbia, and the less seasonal, Dorset, Rambouillet and Finn(183). The variations among breeds and among individuals, suggest genetic basis of seasonality. The above was corroborated, because the seasonality does not disappear when tempered breeds are transported closer the Ecuador, where variations of photoperiod are lower during the year(184). The above possibilities making crosses between breeds or individuals genetically less affected by photoperiod $(148,183)$.

Seasonality can be seen as a problem for the sheep industry to reduce the effectiveness of reproductive programs, at certain times of the year. However, through management of environmental, hormonal, or genetic factors, it is possible to lessen the duration and benefit from the application of focused production systems to produce more than one birth per year.

\section{CONCLUSIONS}

Despite significant achievements, much research is still needed in the field of sexual behavior of the ram. It is required to apply modern research techniques to have a greater understanding of the neuro-physiological processes around this issue, as well as the improvement of management techniques applied to the reproduction, to increase overall productive efficiency. In addition, there are topics where scientific information is particularly scarce, as in the case of tropical breeds. This offers a very broad field of research on a particular model for the study of these behaviors.

End of english version

ver reflejado en el restablecimiento de la libido y concentración espermática del carnero, como se ha demostrado en el macho cabrío $(157,158)$.

Otras prácticas comúnmente usadas en la colección de semen de otros rumiantes como el prevenir el contacto físico con el animal 
estímulo después de la primer eyaculación tampoco ha demostrado tener algún efecto en los carneros(156).

Una variante del uso de la vagina artificial, consiste en un dispositivo que se coloca en la vagina de las ovejas y se recupera después de que el carnero eyacula en ella, lo que tiene la vantaja de no requerir entrenamiento de los machos para tolerar la presencia del humano y el contacto de éste con sus genitales para dirigir el pene hacia la vagina artificial(159).

Una técnica de colección de semen, utilizada en aquellos machos que no han sido entrenados para trabajar con una vagina artificial, con problemas de patas, columna o falta de libido, es la electro-eyaculación. Sin embargo, esta técnica debe evitarse, debido a que puede transmitir defectos a sus crías, que no se observan durante el proceso de colección, como son: la falta o poco interés sexual, debilidad de patas, problemas de erección, entre otros. Además, la electro-eyaculación no siempre culmina en la producción de un eyaculado; estos son de menor calidad que los obtenidos con vagina artificial y la técnica produce elevados índices de estrés en los animales(160), generando consideraciones sobre el bienestar de los mismos. Se ha demostrado que durante la electo-eyaculación, la electricidad aplicada induce cambios relevantes en la frecuencia cardiaca y niveles de cortisol de los carneros(161), por lo que se ha prohibido su uso en algunos países(162). En el caso de ser indispensable su aplicación, es imprescindible el asociarla con algún tratamiento anestésico para reducir sus efectos estresantes en el animal(163).

La inseminación artificial es una técnica muy difundida, sobre todo en países con tradición ovina, y que ofrece grandes ventajas sobre todo en lo que respecta al tema genético. La técnica más difundida para colección de semen con este propósito es el uso de vagina artificial, y hoy en día se sigue avanzando en el conocimiento de cómo afectan algunos factores conductuales el desempeño de carneros destinados a este propósito. Factores como la frecuencia de eyaculación, abstinencia $(147,164)$ o su relación con la libido y ontogenia(165).

\section{ESTACIONALIDAD}

En la mayoría de las razas, los carneros son estacionales y muestran mayor libido durante los días cortos, coincidiendo con el reinicio de la actividad ovárica en la hembra(3). Este ritmo reproductivo está controlado por el fotoperiodo(166). La retina del ojo capta la luz del día y transmite la información a través del nervio óptico hacia el núcleo supraquiasmático, al núcleo paraventricular y a la médula espinal, de donde emergen nervios hasta la glándula pineal, donde el estímulo nervioso se convierte en un estímulo hormonal, secretando melatonina durante las horas de obscuridad. La melatonina en el carnero (reproductores durante días cortos) es capaz de estimular la liberación de la hormona liberadora de gonadotropinas (Gn-RH) en el hipotálamo anterior, promoviendo la secreción de gonadotropinas y la actividad gonadal(167,168).

En el aparato reproductor masculino de otras especies, se han localizado receptores de melatonina(169), por lo que se ha propuesto que esta hormona es capaz de modular la morfología de los túbulos seminíferos(170), las células de Leydig(171) y con ello la secreción de testosterona(169). También existen receptores de melatonina en el epidídimo(172), próstata(173,174) y sobre los mismos espermatozoides(175).

Las hormonas tiroideas también son un componente importante en la estacionalidad. La extirpación de la glándula tiroides termina con los patrones estacionales en la actividad reproductiva(176).

Las razas de ovinos originarias de climas templados en latitudes medias o altas son animales estacionales(177). Sin embargo, en cuanto al efecto del fotoperiodo en los carneros de pelo los resultados en la literatura son variables. En ambientes tropicales y 
subtropicales algunas razas pueden verse muy poco o no afectadas por las variaciones estacionales en las horas luz(178) o temperatura $(76,179)$, pero sí por los cambios en la disposición de alimento durante el año(180).

Al manejar cambios de horas luz en forma controlada, se observa gran variación entre razas. Habiendo razas que son menos suceptibles al fotoperiodo que otras. Por ejemplo, El-Alamy et al(181) obtuvieron cerca del doble de eyaculados en carneros Finn que en Dorset. Además, esta diferencia en libido fue asociada con mayores concentraciones de espermatozoides en los carneros Finn. Aparentemente, los cambios en el fotoperiodo no afectaron la concentración de semen en los carneros Finn. Hormonalmente, 16 h luz, produjeron incrementos en los niveles de prolactina de ambas razas, pero particularmente altos en los carneros Finn, aunque los niveles de testosterona en ambas razas no se vieron afectados.

El consenso general es que los machos se ven menos afectados que las hembras, y aunque disminuída, conservan su capacidad fecundante todo el año(130). Así mismo, también existen variaciones entre individuos. Estas últimas puede deberse al menos en parte a que la reproducción estacional y los mecanismos endocrinos involucrados pueden verse afectados por estímulos conductuales que emergen de las relaciones sociales que los animales establecen con otros de su misma especie. Por ejemplo, Aguirre et al(182) demostraron que la magnitud del efecto estacional no fue suficiente para evitar que los carneros pudiesen ser utilizados como reproductores a lo largo de todo el año. Sin embargo, afectaron de diferente manera a los machos, dependiendo de su jerarquía en el hato. Los carneros dominantes se ven influenciados mayormente por el fotoperiodo, disminuyendo sus tiempos de reacción, incrementando la concentración de testosterona y produciendo mayor cantidad de espermatozoides por eyaculado que los machos sumisos durante los meses de otoño e invierno. Otro factor que identificaron los mismos autores(147), fue la frecuencia de colección. Los carneros sometidos a altas tasas de colección mostraron mayor libido y niveles de testosterona en días cortos, que carneros sometidos a tasas de colección menores.

Entre las razas originarias de climas templados, las más estacionales, son la Suffolk, Hampshire y Columbia, y las menos estacionales, Dorset, Rambouillet y Finn(183). Las variaciones entre razas y entre individuos, sugieren bases genéticas de la estacionalidad, lo cual se corrobora, porque la estacionalidad no desaparece cuando las razas de origen templado son trasladadas más cerca del Ecuador, donde las variaciones del fotoperiodo son menores durante el año(184). Lo anterior, ofrece posibilidades de hacer cruzamientos entre razas o individuos genéticamente menos afectados por el fotoperiodo $(148,183)$.

La estacionalidad puede verse como un problema para la industria ovina al reducir la efectividad de programas reproductivos, a ciertas épocas del año. Sin embargo, a través del manejo de factores ambientales, hormonales, o genéticos, es posible disminur su duración y aprovechar la aplicación de sistemas productivos enfocados a producir más de un parto por año.

\section{CONCLUSIONES}

Pese a logros importantes, aún es necesaria mucha investigación en el campo del comportamiento sexual del carnero. Se requiere aplicar técnicas modernas de investigación para tener un mayor entendimiento de los procesos neuro-fisiológicos alrededor de este tema, así como el mejoramiento de técnicas de manejo aplicadas a la reproducción con vistas a incrementar la eficiencia productiva en general. Aunado a lo anterior, existen temas donde la información científica es particularmente escasa, como el caso de las razas tropicales. Lo anterior, ofrece un campo de investigación muy amplio en una especie modelo particular para el estudio de estas conductas. 


\section{LITERATURA CITADA}

1. Sarlós $\mathrm{P}$, Egerszegi I, Balogh $\mathrm{O}$, Molnár $\mathrm{A}$, Cseh S, Rátky J. Seasonal changes of scrotal circumference, blood plasma testosterone concentration and semen characteristics in Racka rams. Small Ruminant Res 2013: [En prensa].

2. D'Occhio MJ, Brooks DE. Threshold of plasma testosterone required for normal mating activity in male sheep. Horm Behav 1982; 16(4):383-394.

3. Perkins A, Roselli CE. The ram as a model for behavioral neuroendocrinology. Horm Behav 2007;52(1):70-77.

4. Price EO, Borgwardt R, Orihuela A, Dally MR. Sexual stimulation in male sheep and goats. Appl Anim Behav Sci 1998; 59(4): 317-322.

5. Katz LS, Price EO, Wallach SJ R, Zenchak JJ. Sexual performance of rams reared with or without females after weaning. J Anim Sci 1988;66(5):1166-1173.

6. Carlson NR. Fisiologia de la conducta. 8va ed. New Jersey, USA: Pearson \& Adisson Wesley; 2007.

7. Vázquez $R$, Orihuela $A$. Effect of vaginal mucus and urine from ewes in estrus on plasma testosterone levels and weight gain of feedlot rams. Small Ruminant Res 2001; 42(3): 171-175.

8. Aller JF, Aguilar D, Vera T, Almeida GP, Alberio RH. Seasonal variation in sexual behavior, plasma testosterone and semen characteristics of Argentine Pampinta and corriedale rams. Spanish J Agr Res 2012; 10(2):345-352.

9. Gundoðan M, Demirci E. Monthly changes in some reproductive parameters and in testosterone and thyroxine values of rams throughout one year under continental climate conditions. Dtsch Tierarztl Wochenschr 2003;110(11):450-453.

10. Pinckard KI, Stellflug J, Stormshak F. Influence of castration and estrogen replacement on sexual behavior of femalesoriented, male-oriented, and asexual rams. J Anim Sci 2000; 78(7): 1947-1953.

11. Roselli CE, Stormshak F, Stellflug J N, Resko J A. Relationship of serum testosterone concentration to mate preferences in rams. Biol Reprod 2002;67(1):263-268.

12. Parthasarathy V, Price EO, Orihuela A, Dally MR, Adams TE. Passive immunization of rams (Ovis aries) against GnRH: effects on antibody titer, serum concentrations of testosterone, and sexual behavior. Anim Reprod Sci 2002; 74(3-4):203-215.

13. Kiyma Z, Adams TE, Hess BW, Riley ML, Murdoch WJ, Moss GE. Gonadal function, sexual behavior, feedlot performance, and carcass traits of ram lambs actively immunized against GnRH. J Anim Sci 2000; 78(9):2237-2243.

14. Cui S, Chen YF, Yue HN, He YQ, McNeilly AS. Sexual development and the effects of active immunization against $\mathrm{GnRH}$ in Chinese Tanyang ram lambs. Anim Reprod Sci 2003; 77(3-4): 129-139.

15. Jabbour HN, Lincoln GA. Prolactin receptor expression in the testis of the ram: localisation, functional activation and the influence of gonadotrophins. Mol Cell Endocrinol 1999; 25: 148(1-2): 151-61.

16. Gerlach T, Aurich JE. Regulation of seasonal reproductive activity in the stallion, ram and hamster. Anim Reprod Sci 2000; 15; 58(3-4): 197-213.

17. Gloria E, Regisford C, Katz LS. Effects of bromocriptine treatment on the expression of sexual behavior in male sheep (Ovis aries). J Anim Sci 1994; 72(3):591-597.
18. Maran RRM, Arunakaran J, Aruldhas MM. Prolactin and Leydig cells: biphasic effects of prolactin on LH-, T3- and $\mathrm{GH}$ - induced testosterone/oestradiol secretion by Leydig cells in pubertal rats. Int J Androl 2001;24(1):48-55.

19. Sanford LM, Baker SJ. Prolactin regulation of testosterone secretion and testes growth in DLS rams at the onset of seasonal testicular recrudescence. Reproduction 2010;139(1):197-207.

20. Sharma SC, Fitzpatrick RJ, Ward WR. Coital-induced release of oxytocin in the ram. J Reprod Fertil 1972;31(3):488-489.

21. Knight T. Ram induced stimulation of ovarian and oestrous activity in anoestrous ewes - a review. Proc New Zeal Soc Anim Prod 1983;43:7-11.

22. Whittington $K$, Assinder SJ, Parkinson T, Lapwood KR, Nicholson HD. Function and localization of oxytocin receptors in the reproductive tissue of rams. Reprod 2001; 122(2):31725.

23. Vignozzi L, Filippi S, Morelli A, Luconi M, Jannini E, Forti G, Maggi $M$. Regulation of epididymal contractility during semen emission, the first part of the ejaculatory process: a role for estrogen. J Sex Med 2008;5(9):2010-2016.

24. Hull EM, Rodríquez-Manzo G. Brain and Behavior. $2^{\text {nd }}$ ed. USA: Elsevier Inc; 2009:5-66.

25. Borg KE, Esbenshade KL, Johnson BH, Lunstra DD, Ford JJ. Effects of sexual experience, season, and mating stimuli on endocrine concentrations in the adult ram. Horm Behav 1992; 26(1): 87-109.

26. Roselli CE, Larkin K, Rsko JA, Stellflug JN, Stormshak F. The volume of a sexually dimorphic nucleus in the ovine medial preoptic area/anterior hypothalamus varies with sexual partner preference. Endocr J 2004;145(2):478-483.

27. Alexander BM, Stellflug JN, Rose JD, Fitzgerald JA, Moss GE. Behavior and endocrine changes in high-performing, low-performing, and male-oriented domestic rams following exposure to rams and ewes in estrus when copulation is precluded. J Anim Sci 1999;77(7):1869-1874.

28. Roselli CE, Resko JA, Stormshak F. Hormonal influences on sexual partner preference in rams. Archives Sex Behav 2002;31(1):43-49.

29. Roselli CF. Brain aromatasa: Roles in reproduction and neuro protection. J Steroid Bioquem 2007; 106(1-5):143-150.

30. Perkins A, Fitzgerald JA, Moss GE. A comparison of LH secretion and brain estradiol receptors in heterosexual and homosexual rams and female sheep. Horm Behav 1995;29(1):31-41.

31. Ruckstuhl KE, Neuhaus P. Sexual segregation in ungulates: A new approach. Behav 2000;137(3):361-377.

32. Grubb P. The rut and behaviour of Soay rams. In: J ewell PA, Milner C, Boyd J M. editors, I sland Survivors: The Ecology of the Soay sheep of St. Kilda. 1st ed. London, UK: The Athlone Press of the University of London; 1974: 195-223.

33. Pumberton JM, Preston BT, Stevenson IR, Wilson K. Dominant rams lose out by sperm depletion. A Waning success in siring counters a ram's high score in competition for ewes. Nature 2001;409(6821):681-682.

34. Pepelko WE, Clegg MT. Influence of season of the year upon patterns of sexual behavior in male sheep. J Anim Sci 1965;24(3):633-637.

35. Pepelko WE, Clegg MT. Studies on mating behavior and some factors influencing the sexual response in the male sheep Ovis aries. Anim Behav 1965;13(2-3):249-258. 
36. Lincoln GA, Lincoln CE, McNeilly AS. Seasonal cycles in the blood plasma concentration of IFSH, inhibin and testosterone, and testicular size in rams of wild, feral and domesticated breeds of sheep. J Reprod Fert 1990;88:623-633.

37. Cottrell DF, Iggo A, Kitchell RL. Electrophysiology of the afferent innervation of the penis of the domestic ram. J Physiol 1978;283:347-367.

38. Kirk EJ, Kitchell RL, Carr DH. Neurophysiologic maps of cutaneous innervation of the external genitalia of the ram. Am J Vet Res 1987;48(7):1162-6.

39. Odagiri K, Matsuzawa Y, Yoshikawa Y. Analysis of sexual behavior in rams (Ovis aries). Exp Anim Jpn Assoc Lab Anim Sci 1995; 44(3): 187-192.

40. Bland K.P, Jubilan BM. Correlataion of flehmen by male sheep with female behavior and oesttrus. Anim Behav 1987; 35(3) : 735-738.

41. Blissitt MJ , Bland KP, Cottrell DF. Olfactory and vomeronasal chemo-reception and the discrimination of oestrous and non-oestrous ewe urine odours by the ram. Appl Anim Behav Sci 1990;27(4):325-335.

42. Lindsay DR. The importance of olfactory stimuli in the mating behavior of the ram. Anim Behav 1965;13(1):75-78.

43. Bernon DE, Shrestha JN. Sexual activity patterns in rams. Can J Comp Med 1984;(1):42-46.

44. Banks EM. Some aspects of sexual behavior in domestic sheep, Ovis aries. Behav 1964;23(3-4):249-278.

45. Ungerfeld R, González-Pensado SP. Social dominance and courtship and mating behavior in rams in non-competitive and competitive pen tests. Reprod Domes Anim 2009; 44(1):44-47.

46. Beamer W, Bermant G, Clegg MT. Copulatory behavior of the ram. Ovis aries. II. Factors affecting copulatory satiation. Anim Behav 1969;17(4):706-711.

47. Alexander G, Signoret JP, Hafez ESE. Sexual and maternal behavior. In: Hafez ESE editor, Reproduction in farm animals. $3^{\text {rd }}$ ed. Philadelphia, Philadelphia, USA: Lea and Febiger; 1974:222-254.

48. Dewsbury DA. Effects of novelty on copulatory behavior: The coolidge effect and related phenomena. Psychological Bull 1981;89(3):464-482.

49. Lynch JJ, Hinch GN, Adams DB. The Behaviour of Sheep. Biological principles and implication for production. 1st ed. Sidney, Australia: CAB International and CSIRO Publications; 1992.

50. Clemente N, Orihuela A, Flores-Pérez FI, Aguirre V, Valencia J. Reproductive activity of Saint Croix and Suffolk rams at medium latitudes $\left(19^{\circ} \mathrm{N}\right)$ during long days while being exposed to Suffolk ewes in seasonal anestrus. Arch Med Vet 2013;45:67-70.

51. Raadsma HW, Edey TN. Mating performance of paddockmated rams. II. Changes in sexual and general activity during the joining period. Anim Reprod Sci 1985; 8(1-2): 101107.

52. Clemente N, Orihuela A, Flores-Pérez I, Aguirre V, Valencia J. 2013. Reproductive behaviour of Saint Croix and Suffolk rams at medium latitudes (19o $\mathrm{N}$ ) during long days while being exposed to Suffolk ewes in seasonal anestrus. Arch Med Vet 45;67-70.

53. Price EO. Principles and Applications of Domestic Animal Behavior. 1st ed. Cambridge, UK: Cambridge University Press; 2008:107.
54. Bench DJ, Price EO, Dally MR, Borgwardt RE. Artificial selection of rams for sexual performance and its effect on the sexual behavior and fecundity of male and female progeny. Appl Anim Behav Sci 2001;72(1-2):41-50.

55. Snowder GD, Stellflug J N, Van Vleck LD. Heritability and repeatability of sexual performance scores of rams. J Anim Sci 2002;80(6):1508-1511.

56. Kridli RT, Momany Shaker M, Abdullah AY, Muwalla MM. Sexual behaviour of yearling Awassi, Charollais x Awassi and Romanov $x$ Awassi rams exposed to oestrous Awassi ewes. Trop Anim Health Prod 2007;39(3):229-235.

57. Roselli CE, Schrunk J M, Stadelman HL, Resko JA, Stormshak F. The effect of aromatase inhibition on the sexual differentiation of the sheep brain. Endocrine 2006;29(3):501511.

58. Gorton LM, Mahoney MM, Magorien JE, Lee TM, Wood RI. Estrogen receptor immunoreactivity in late-gestation fetal lambs. Biol Reprod 2009;80(6)1152-1159.

59. Fitzgerald JA, Perkins A, Hemenway K.Relationship of sex and number of siblings in uterus with sexual behavior of mature rams. Appl Anim Behav Sci 1993;38(3-4):283-290.

60. Roselli CE, Stormshak F. The ovine sexually dimorphic nucleus, aromatase, and sexual partner preferences in sheep. J Steroid Biochem 2010; 118(4-5):252-256.

61. Resko JA, Perkins A, Roselli CE, Stellflug J N, Stormshak FK. Sexual behaviour of rams: male orientation and its endocrine correlates. J Reprod Fertil 1999;54(Suppl):259-269.

62. Vasey PL. Same-sex sexual partner preference in hormonally and neurologically unmanipulated animals. Ann Rev Sex Res 2002; 13: 141-179.

63. Kendrick KM, Hinton MR, Atkins K, Haupt MA, Skinner JD. Mothers determine sexual preferences. Nature. 1998; 17: 395(6699): 229-230.

64. Tomlinson KA, Price EO. The establishment and reversibility of species affinities. Anim Behav 1980;28(2):325-330.

65. Fagen R. Animal Play Behavior. $1^{\text {st }}$ ed. New York, USA: Oxford University Press; 1981.

66. Orgeur P. Sexual play behavior in lambs androgenized in utero. Physiol Behav 1995;57(1): 185-187.

67. Vázquez R, Orihuela A, Aguirre V. A note on the effect of number and sex of contemporary siblings on sexual play behavior of lambs (Ovis aries). [datos no publicados].

68. Simitzis PE, Deligeorgis SG, Bizelis JA. Effect of breed and age on sexual behavior of rams. Theriogenology 2006; 65(8): 1480-1491.

69. Price EO, Katz LS, Wallach SJ R, Zenchak JJ. The relationship of male-male mounting to the sexual preferences of young rams. Appl Anim Behav Sci 1988;21(4):347-355.

70. Tilbrook AJ, Galloway DB, Williams AH, Clarke IJ. Treatment of young rams with an agonist of $\mathrm{GnRH}$ delays reproductive development. Horm Behav 1993; 27(1):5-28.

71. Price EO, Estep DQ, Wallach SJ, Dally MR. Sexual performance of rams as determined by maturation and sexual experience. J Anim Sci 1991;69(3):1047-1052.

72. Price EO, Orihuela A, Parthasarathy V, Borgwardt R, Dally MR. Yearling rams initially disinterested in estrous ewes subsequently exhibit subnormal sexual performance. Appl Anim Behav Sci 1999;64(4):235-240.

73. Stellflug JN, Lewis GS. Effect of early and late exposure to estrual ewes on ram sexual performance classifications. Anim Reprod Sci 2007;97(3-4):295-302. 
74. Kridli RT, Abdullah AY, Momani Shaker M, Mahmoud KZ. Sexual performance of rams sequentially exposed to shorttailed and fat-tailed ewes. Reprod Domest Anim 2008; 43(4): 497-501.

75. Fthenakis G.C., Karagiannidis A., Alexopoulos C., Brozos C., Saratsis P., Kyriakis S. Clinical and epidemiological findings during ram examination in 47 flocks in southern Greece. Prev Vet Med 2001;52,43-52.

76. Godfrey RW, Collins JR, Gray ML. Evaluation of sexual behavior of hair sheep rams in a tropical environment. J Anim Sci 1998; 3(76): 714-717.

77. Zenchak JJ, Katz LS, Price EO, Wallach SJR. Sexual behavior of rams as influenced by the degree of restraining estrous ewes and by the additional presence of anestrous ewes. J Anim Sci 1988;66(11):2851-2855.

78. Stellflug JN, Cockett NE, Lewis GS. Relationship between sexual behavior classifications of rams and lambs sired in a competitive breeding environment. J Anim Sci 2006; 84(2): 463-468.

79. Price EO, Borgwardt R, Dally MR, Hemsworth PH. Repeated matings with individual ewes by rams differing in sexual performance. J Anim Sci 1996; 74(3):542-544.

80. Stellflug J N, Lewis GS, Moffet CA, Leeds TD. Evaluation of three-ram cohort serving capacity tests as a substitute for individual serving capacity tests. J Anim Sci 2008; 86(8): 2024-2031.

81. Lindsay DR, Dunsmore DG, Williams JD, Syme GJ. Audience effects on mating behavior of rams. Anim Behav 1976;24(4): 818-821.

82. Price EO, Wallach SJ R, Dally MR. Effects of sexual stimulation on the sexual performance of rams. Appl Anim Behav Sci 1991; 30(3): 333-340.

83. Price EO, Borgwardt R, Orihuela A, Dally MR. Sexual stimulation in male sheep and goats. Appl Anim Behav Sci 1998; 59(4): 317-322.

84. Maina D, Katz L. Scent of a ewe: transmission of a social cue by conspecifics affects sexual performance in male sheep. Biol Reprod 1999;60(6):1373-1377.

85. Lezama V, Orihuela A, Angulo R. Sexual behavior and semen characteristics of rams exposed to their own semen or semen from a different ram on the vulva of the ewe. Appl Anim Behav Sci 2001;75(1):55-60.

86. Price EO, Borgwardt R, Dally MR. Effect of ewe restraint on the libido and serving capacity of rams. Appl Anim Behav Sci 1993;35(4):339-345.

87. Price EO, Borgwardt R, Dally MR. Measures of libido and their relation to serving capacity in the ram. J Anim Sci 1992; 70(11):3376-3380.

88. Perkins A, Fitzgerald JA, Price EO. Sexual performance of rams in serving capacity tests predicts success in pen breeding. J Anim Sci 1992;70(9):2722-2725.

89. Stellflug J N, Cockett NE, Lewis GS. The influence of breeding intensity on above- and below-average sexual performance rams in single- and multiple-sire breeding environments. Anim Reprod Sci 2008; 104(2-4):248-256.

90. Stellflug J N, Berardinelli JG. Ram mating behavior after long-term selection for reproductive rate in Rambouillet ewes. J Anim Sci 2002;80(10):2588-2593.

91. Stellflug JN. Use of naloxone challenge to predict sexual performance of young rams. J Anim Sci 2003;81(9):21112117.
92. Stellflug JN, Perkins A, LaVoie VA. Testosterone and luteinizing hormone responses to naloxone help predict sexual performance in rams. J Anim Sci 2004;82(11):33803387.

93. Langbein J, Puppe B. Analuysing dominance relationships by sociometric methods - a plea for a more stadardised and precise approach in farm animals. Appl Anim Behav Sci 2004;87(3-4):293-315.

94. Fowler DG, Jenkins LD. The effects of dominance and infertility of rams on reproductive performance. Appl Anim Ethol 1976;2(4):327-337.

95. Erhard HW, Price EO, Dally MR. Competitive ability of rams selected for high and low levels of sexual performance. Anim Sci 1998;66(2)403-408.

96. Preston BT, Stevenson IR, Pemberton JM, Coltman DW, Wilson K. Overt and covert competition in a promiscuous mammal: the importance of weaponry and testes size to male reproductive success. Proc Biol Sci 2003;270(1515): 633-640.

97. Pelletier F. Foraging time of rutting bighorn rams varies with individual behavior, not mating tactic. Behav Ecol 2005; 16(1)280-285.

98. Craig JV. Domestic animal behaviour: causes and implication of animal care and management. $1^{\text {st }}$ ed. New Jersey, USA: Prestice-Hall; 1981.

99. Lovari S, Ale SB. Are there multiple mating strategies in blue sheep? Behav Process 2001;53(1-2):131-135.

100. Pelletier F, Bauman J, Festa-Bianchet M. Fecal testosterone in bighorn sheep (Ovis canadiensis): behavioural and endocrine correlates. Can J Zool 2003;81(10):1678-1684.

101. González-Pensado SP, Núñez ML, Ungerfeld R. Relación entre la posición jerárquica de los carneros y la edad, peso, presencia de cuernos, y circunferencia escrotal [resumen]. Primeras Jornadas Uruguayas de Comportamiento Animal. Montevideo, Uruguay. 2006;39.

102. Ungerfeld R, Lacuesta L. Social rank during pre-pubertal development and reproductive performance of adult rams. Anim Reprod Sci 2010;121(1-2): 101-105.

103. Ungerfeld $R$, Núñez ML. Jerarquía y dominancia en grupos de carneros: establecimiento y efectos sobre la reproducción. Veterinaria [en prensa].

104. Ungerfeld R. Sexual behavior of medium-ranked rams toward non-estrual ewes is stimulated by the presence of low-ranked rams. J Vet Behav [en prensa].

105. Dimas PD, Orihuela A, Flores-Pérez FI, Aguirre FV. Conducta sexual y características del semen de carneros dominantes y/o sumisos colectados en presencia de otro macho [resumen]. XLVII Reunión Nacional de Investigación Pecuaria. León, Gto. 2011:100.

106. Hulet CV, Blackwell RL, Encanbrack SK, Price DA, Wilson LO. Mating behavior of the ewe. J Anim Sci 1962; 21(4):870-874.

107. Preston BT, Stevenson IR, Pemberton JM, Wilson K. Dominant rams lose out by sperm depletion. Nature 2001; 409(6821):681-682.

108. López $\mathrm{H}$, Orihuela $\mathrm{A}$. Relation between a test assessing sexual motivation of the ram and reproductive success during single and multiple-sire matings. [Unpublished data].

109. Hulet CV. Behavioral, social and psychological factors affecting mating time and breeding efficiency in sheep. J Anim Sci 1966;25(1):5-20. 
110. Tilbrook AJ, Cameron AWN, Lindsay DR. The influence of ram mating preferences and social interaction between rams on the proportion of ewes mated at field joining. Appl Anim Behav Sci 1987;18(2):173-184.

111. Jewell PA, Hall SJG, Rosenberg MM. Multiple mating and string success during natural oestrus in the ewe. J Reprod Fert 1986; 77(1):81-89.

112. Preston BT, Stevenson IR, Wilson K. Soay rams target reproductive activity towards promiscuous females' optimal insemination period. Proc Royal Soc Biol Sci (Series B) 2003; 270(1528):2073-2078.

113. Tilbrook AJ, Pearce DT. Pattern of loss of spermatozoa from the vagina of the ewe. Aust Biol Sci 1986;39(3):295303.

114. Castrillejo A. Relevamiento clínico de aptitud de reproductiva en carneros. Vet 1990;26:15-32.

115. Signoret JP. Influence of the sexual receptivity of a teaser ewe on the mating preference in the ram. Appl Anim Ethol 1975; 1(3):229-232.

116. Price EO, Blackshaw JK, Blackshaw A, Borgwardt R, Dally $M R$, Bondurant RH. Sexual responses of rams to ovariectomized and intact estrous ewes. Appl Anim Behav Sci 1994;42(1):67-71.

117. Tilbrook AJ. The influence of factor associated with oestrus on the sexual attractiveness of ewes to rams. Appl Anim Behav Sci 1987;17(1-2):117-128.

118. Ungerfeld $R$, Silva $L$. The presence of normal vaginal flora is necessary for normal sexual attractiveness of ewes. Appl Anim Behav Sci 2005;93(3-4):245-50.

119. Suárez G, Zunino $P$, Carol $H$, Ungerfeld R. Changes in the aerobic vaginal bacterial mucous load and assessment of the susceptibility to antibiotics after treatment with intravaginal sponges in anestrous ewes. Small Ruminant Res 2006;63(1-2):39-43.

120. Gatti M, Olivera C, Zunino P, Ungerfeld R. El uso de esponjas intravaginales con progestinas para sincronizar celos disminuye la atractividad de las ovejas en celo [resumen]. Primer Congreso Latinoamericano de Etología Aplicada. Montevideo, Uruguay. 2008:72.

121. Tilbrook AJ. Physical and behavioural factors affecting the sexual "attractiveness" of the ewe. Appl Anim Behav Sci 1987; 17(1-2): 109-115.

122. Tilbrook AJ, Cameron AWN. Ram mating preferences for woolly rather than shorn ewes. Appl Anim Behav Sci 1989; 24(4):301-312.

123. Houpt KA. Domestic Animal Behavior for Veterinarians and Animal Scientists. $3^{\text {rd }}$ ed. Ames, Iowa, USA; Iowa State University Press; 1998:135.

124. Hayman RH. Exercise of mating preference by a Merino ram. Nature 1964;203(4941): 160-162.

125. Lees JL, Weatherhead M. A note on mating preferences of Clun Forest ewes. Anim Prod 1970;12(1):173-175.

126. Orihuela A, Vázquez R. Mating preferences of Saint Croix rams to related or unrelated ewes. Small Ruminant Res 2009;83(1): 82-84.

127. Preston BT, Stevenson IR, Pemberton JM, Coltman DW, Wilson K. Male mate choice influences female promiscuity in Soay sheep. Proc Royal Soc Biol Sci (Series B) 2005; 272(1561): 365-373.

128. Coltman DW, Bancroft DR, Rogertson A, Smith J A, CluttonBrock TH, Pemberton J M. Male reproductive success in a promiscuous mammal: behavioural estimates compared with genetic paternity. Mol Ecol 1999;8(7):199-1209.

129. Orihuela A. Assessing female promiscuity from behavioral observation beyond male influence in Saint Croix Ewes. J Anim Vet Adv 2009;8(12):2708-2712.

130. Rosa HJD, Bryant MJ. Review. The 'ram effect' as a way of modifying the reproductive activity in the ewe. Small Ruminant Res 2002;45(1):1-16.

131. Ungerfeld $R$, Forsberg $M$, Rubianes $E$. Overview of the response of anoestrous ewes to the ram effect. Reprod Fert Develop 2004; 16(4):479-490.

132. Delgadillo JA, Gelez H, Ungerfeld R, Hawken PAR, Martin GB. The "male effect" in sheep and goats - Revisiting the dogmas. Behav Brain Res 2009;200(2)304-314.

133. Perkins A, Fitzgerald JA. The behavioral component of the ram effect: the influence of ram sexual behavior on the induction of estrus in anovulatory ewes. J Anim Sci 1994; 72(1):51-55.

134. Cushwa WT, Bradford GE, Stabenfeldt GH, Berger YM, Dally MR. Ram influence on ovarian and sexual activity in anestrous ewes: effects of isolation of ewes from rams before joining and date of ram introduction. J Anim Sci 1992; 70(4): 1195-1200.

135. Ekiz EE, Matur E, Arslan M, Akyazi I, Ozcan M. Influence of ram presence (permanent vs. intermittent) on estrus parameters and behaviours in Kivircik ewes. Deut Tierarzt| Woch 2009; 116(7):260-265.

136. Hawken PAR, Beard AP. Ram novelty and the duration of ram exposure affects the distribution of mating in ewes exposed to rams during the transition into the breeding season. Anim Reprod Sci 2009; 111(2-4):249-260.

137. Kenyon PR, Morel PCH, Morris ST, West DM. The effect of individual live weight and use of teaser rams prior to mating on the reproductive performance of ewe hoggets. N Z Vet J 2005;53(5):340-343.

138. Hawken PAR, Evans ACO, Beard AP. Short term, repeated exposure to rams during the transition into the breeding season improves the synchrony of mating in the breeding season. Anim Reprod Sci 2008; 106(3-4):333-344.

139. Ungerfeld R. Combination of the ram effect with PGF2alpha estrous synchronization treatments in ewes during the breeding season. Anim Reprod Sci 2011;124(1-2):65-68.

140. Ungerfeld R, Silva L. Ewe effect: Endocrine and testicular changes in experienced adult and inexperienced young Corriedale rams used for the ram effect. Anim Reprod Sci 2004;80(3-4):251-259.

141. Kenyon P, Morris S, West D. Can Romney lambs whose scrotums have been shortened by the use of a rubber ring be used as an alternative to vasectomised Perendale rams for inducing early breeding activity in Romney ewe lambs?. N Z Vet J 2008;56(6):326-329.

142. Ungerfeld R, Ramos MA, Gonzalez-Pensado SP. Ram effect: Adult rams induce a greater reproductive response in anestrous ewes than yearling rams. Anim Reprod Sci 2008; 103(3-4): 271-277.

143. Rosa HJD, Juniper DT, Bryant MJ. Effects of recent sexual experience and melatonin treatment of rams on plasma testosterone concentration, sexual behavior and ability to induce ovulation in seasonally anoestrous ewes. J Reprod Fertil 2000;120(1):169-176. 
144. Nugent RA, Notter DR. Effect of cohabitation with whitefaced ewes on estrous activity of Hampshire and Suffolk ewes exposed to rams in June. J Anim Sci 1990;68(6): 1513-1519.

145. Hanif M, Williams HL. The effect of melatonin and light treatment on reproductive performance of yearling Suffolk rams. $\mathrm{Br}$ Vet J 1991;147(1):49-56.

146. Schanbacher BD. Responses of market lambs and Suffolk rams to a stimulatory skeleton photoperiod. Reprod Nutr Dev 1988;28(2B): 431-441.

147. Aguirre FV, Orihuela A, Vázquez RR. Effect of semen collection frequency on seasonal variation in sexual behavior, testosterone, testicular size and semen characteristics of tropical hair rams (Ovis aries). Trop Anim Health Prod 2007;39(4):271-277.

148. Arroyo LJ, Gallegos-Sánchez J, Villa-Godoy A, Berruecos J M, Perera G, Valencia J. Reproductive activity of Pelibuey and Suffolk ewes at $19^{\circ}$ north latitude. Anim Reprod Sci 2007; 102(1-2):24-30.

149. Clemente N, Orihuela A, Flores-Pérez FI, Aguirre V, Ortiz A, Solano JJ, Valencia J. Reproductive activity of Suffolk ewes in seasonal anestrus after being exposed to Saint Croix or Suffolk rams. Appl Anim Res 2012;40(3):203207.

150. Zúñiga $O$, Forcada $F$, Abecia JA. The effect of melatonin implants on the response to the male effect and on the subsequent cyclicity of Rasa Aragonesa ewes implanted in April. Anim Reprod Sci 2002;72(3-4):165-174.

151. Hawken PA, Beard AP, O'Meara CM, Duffy P, Quinn KM, Crosbhy TF, Boland MP, Evans AC. The effects of ram exposure during progegen oestrus synchronization and time of ram introduction post progestagen withdrawal on fertility in ewes. Theriogenology 2005;63(3)860-871.

152. Pevsner DA, Rodrìguez-Islas RM, Ciccioli NH. Ram-induced oestrus and ovulation in lactating and weaned Corriedale ewes. Animal 2010;4(3):472-479.

153. Morales-Terán G, Herrera-Cordero CA, Pérez-Hernández $P$, Salazar-Ortiz J, Gallegos-Sánchez J. Influence of controlled suckling and the male effect on the resumption of postpartum ovarian activity in Pelibuey sheep. Trop Subtrop Agroecosist 2011; 13:493-500.

154. Sánchez-Dávila F, Bernal H, Colín J. Environmental factors and interval from the introduction of rams to estrus in postpartum Saint Croix sheep. Trop Anim Health Prod 2011; 43:887-891.

155. Aguirre FV, Vázquez RR, Orihuela A. Entrenamiento de carneros para recolección de semen mediante vagina artificial, utilizando como estímulo objetos inanimados. Vet Mex 2005;36(1): 105-111.

156. Lezama V, Orihuela A, Angulo R. Effect of restraining rams or change of the stimulus ewe on the libido and semen quality of rams. Small Ruminant Res 2003;49(2):219-222.

157. Prado V, Orihuela A, Lozano S, Pérez-León I. Management of the female stimulus during semen collection and its association with libido re-establishment and semen characteristics of goats. J Anim Sci 2002;80(6):1520-1523.

158. Prado V, Orihuela A, Lozano S, Pérez-León I. Effect on ejaculatory performance and semen parameters of sexuallysatiated male goats (Capra hircus) after changing the stimulus female. Theriogenology 2003;60(2):261-267.
159. Wulster-Radcliffe MC, Williams MA, Stellflug JN, Lewis GS. Artificial vagina vs a vaginal collection vial for collecting semen from rams. J Anim Sci 2001;79:2964-2967.

160. Ax RL, Dally MR, Didion AA, Lenz RW, Love SS, Varner DD, Hafez B, Bellin ME. Artificial insemination. In: Hafez ESE, Hafez B editors. Reproduction in farm animals. $7^{\text {th }}$ ed. New York, USA: Lippincott Williams and Wilkins; 2000: 365-375.

161. Orihuela A, Aguirre V, Hernández C, Flores-Pérez I, Vázquez R. Breaking down the effect of electro-ejaculation on the serum cortisol response, heart and respiratory rates in hair sheep (Ovis aries). J Anim Vet Adv 2009;8(10): 19681972.

162. Palmer CW. Welfare aspects of theriogenology: Investigating alternatives to electro-ejaculation of bulls. Theriogenology 2005;64(3):469-479.

163. Orihuela A, Aguirre V, Hernández C, Flores-Pérez I, Vázquez $R$. Effect of anesthesia on welfare aspects of hair sheep (Ovis aries) during electro-ejaculation. J Anim Vet Adv 2009; 8(2): 305-308.

164. Ollero $M$, Muiño-Blanco T, López-Pérez MJ, Cebrián-Pérez JA. Viability of ram spermatozoa in relation to the abstinence period and successive ejaculations. J Androl 2008; 19(5): 287-292.

165. Orihuela A, Aguirre V. Ontogeny of mating competence and some sexual characteristics in sexually naïve yearling rams (Ovis aries). J Vet Behav 2011;6:205-207.

166. Kumar V. Photoperiodism in higher vertebrates: an adaptive strategy in temporal environment. Indian J Exp Biol 1997; 35: 427-437.

167. Velázquez PM, Gutiérrez-Ruiz J, Prieto-Gómez B. Fertilidad masculina modulada por melatonina. Rev Fac Med UNAM 2011;54:24-33.

168. Ungerfeld R, Bielli A. Animal reproduction in livestock. Seasonal and social factors affecting reproduction. Enyclopedia of Life Support Systems, UNESCO, Eolss Publishers, Oxford, UK. 2012. http:www.eolss.net.

169. Frungieri MB, Mayerhofer A, Ztta K, Pignataro OP, Calandra RS, Gonzalez-Calvar SI. Direct effect of melatonin on Syrian hamster testes: melatonin subtype la receptors, inhibition of androgen production, and interaction with the local corticotropin-releasing hormone system. Endocrinol 2005; 146(3): 1541-1552.

170. Gutierrez-Ruiz J, Granados-Canseco F, Martinez-Esparza C, Velazquez-Paniagua M, Prieto-Gomez. Chronic melatonin application modifies the cytoarchitecture of testis and decreases the sperm number in Wistar rat. Pharmacology on line. 2006; 3:422-427.

171. Yilmaz B, Kutlu S, Mogulkoc R, Canpolat S, Sandal S, Tarakci B, Kelestimur H. Melatonin inhibits testosterone secretion by acting at hypothalamo-pituitary-gonaldal axis in the rat. Neuro Endocrinol Lett 2000;21(4):301-306.

172. Shiu SY, Li L, Siu SW, Xi SC, Fong SW, Pang SF. Biological basis and possible physiological implications of melatonin receptor- mediated signaling in the rat epididymis. Biol Signals Recept 2000;9(3-4):172-87.

173. Gilad E, Laudon M, Matzkin $H$, Zisapel N. Evidence for a local action of melatonin on the rat prostate. J Urol 1998; 159(3): 1069-1073.

174. Tam CW, Chan KW, Liu WW, Pang B, Yao KM, Shiu SY. Melatonin as a negative mutagenic hormonal regulator of 


\section{LA CONDUCTA SEXUAL DEL CARNERO. REVISIÓN}

human prostate epithelial cell growth: potential mechanisms and clinical significance. J Pineal Res 2008; 45(4) : 403-12.

175. Fujinoki M. Melatonin-enhanced hyperactivation of hamster sperm. Reprod 2008;136(5):533-541.

176. Parkinson TJ, Follett BK. Thyroidectomy abolishes seasonal testicular cycles of Soay rams. Proc Royal Soc-Biol Sci (Series B) 1995;259(1354):1-6.

177. Avdi M, Banos G, Stefos K, Chemineau P. Seasonal variation in testicular volume and sexual behavior of Chios and Serres rams. Theriogenology 2004;62(1-2):275-282.

178. Rosa HJD, Bryant MJ. Seasonality of reproduction in sheep. Small Ruminant Res 2003;48(3):155-171.

179. Ibrahim SA. Seasonal variations in semen quality of local and crossbred rams raised in the United Arab Emirates. Anim Reprod Sci 1997;49(2-3):161-167.

180. Galina MA, Morales R, Silva E, López B. Reproductive performance of Pelibuey and Blackbelly sheep under tropical anagement systems in Mexico. Small Ruminant Res 1996;22(1):31-37.

181. El-Alamy MA, Foote RH, Hare E. Sperm output and hormone concentrations in Finn and Dorset rams exposed to long- and short-day lighting. Theriogenology 2001;56(5):839-854.

182. Aguirre FV, Orihuela $A$, Vázquez RR. Seasonal variations in sexual behavior, testosterone, testicular size and semen characteristics, as affected by social dominance, of tropical hair rams (Ovis aries). Anim Sci 2005; 78(4):417-423.

183. Notter DR. Opportunities to reduce seasonality of breeding in sheep by selection. Sheep Goat Res J 2002;17(3):2132.

184. Blache D, Martin GB, Tjondronegoro S, Boukhliq R, Blackberry MA, Briegel JR, Fisher JA, Adams NR. Determinats of the annual pattern of reproduction in mature male Merino and Suffolk sheep: modification of endogenous rhythms by photoperiod. Reprod Fert Develop 1999; 11:355-399. 
Agustín Orihuela Trujillo / Rev Mex Cienc Pecu 2014;5(1):49-89 